\title{
Global Maoism and the Politics of Localization in Peru and Tanzania
}

\section{Matt Galway, The University of British Columbia}

In 1853 Karl Marx wrote in reaction to the Taiping Uprising in China "it may safely be augured that the Chinese revolution will throw a spark into the overloaded mine of the present industrial system and cause the explosion of the long-prepared general crisis, which spreading abroad, will be closely followed by political revolution on the continent."1 Marx may not have been aware of the Christian Taipings' hellfire and brimstone millenarian beliefs, but he saw in their rebellion a spark that could start a prairie fire of political progress. This paper holds Mao Zedong's proposal in 1938 for the "Sinification of Marxism," which referred to specific ways in which the foreign theory of Marxism-Leninism could be adapted to the concrete historical realities of modern China, in the same regard. ${ }^{2}$ The Chinese Communist Party (CCP) officially recognized the Thought of Mao Zedong (later "Maoism") as the guiding ideology of the Chinese Revolution in 1945 after years during which Chinese Marxist intellectuals including Mao attempted to reconcile Marxism with China's specific revolutionary situation. But despite a handful of existing scholarship on Maoism outside China, only a few attempts have been made to subject Mao's groundbreaking concept model to an analysis of its impact in the developing world. ${ }^{3}$

This essay examines two cases through the scope of a twin theoretical focus: O.W Wolters' theory of localization and Mao Zedong's Sinification, which, in Mao's words, means the blending of Marxian universals with the "concrete historical practice of the Chinese revolution" to suit the country's unique historical experience, struggle, and culture (termed by Mao as its "peculiarities"). ${ }^{4}$ The first case, Peru, conveys the ways in which the orthodox Maoist Shining Path appropriated Jose Mariátegui's concept of indigenismo ${ }^{5}$ and Andean cultural and traditional norms. ${ }^{6}$ In so doing, the Party attempted to "localize" Maoism to fit Peru's unique geographical and cultural contexts. The second case in Tanzania, however, provides a counter example. Chinese advisers made concerted efforts to indoctrinate Tanzanians, but African socialismembodied in Nyerere's ujamaa villagization ${ }^{7}$ — prevailed over foreign ideological influences. Nyerere and the Tanganyikan African National Union (TANU), later the Chama Cha Mapinduzi (CCM), drew inspiration from Nyerere's idyllic perception of pre-colonial African life and adapted it to suit Tanzania's current needs rather than espouse a foreign ideology and apply it to local settings. But Ujamaa as a uniquely "African" idea ultimately failed to make the transition from egalitarian theory to practice. 
Abdul Rahman Babu's critique of African socialism, which challenges the idea of harmonious past equality in Africa and forwards material progress and Maoist notions of "voluntariness" and self-reliance as essentials, informs this paper's proposal that some of the major tenets of Maoism provide for an alternative to capitalist development. ${ }^{8}$ Mao's notions of voluntarism, selfreliance, and a worker-peasant alliance may have served as fitting models since Mao's "approach to Marxist analysis of society makes practice primary," and since various socio-political issues arose in Julius Nyerere-era Tanzania due to the failure to fully turn theory into practice during the period of ujamaa villagization. ${ }^{9}$ The study below also intends to convey the difficulty in reconciling theory and practice and to weigh the efficacy of localizing an ideology in settings disparate of its origin.

\section{Twin Theoretical Focus: Localization and Sinification}

Before discussing the case studies, one must first be able to view them through the twin scopes of Wolters' theory on localization and Mao's Sinification.

Historian O.W. Wolters defines the term "localization" as "calling our attention to something else outside the foreign materials." 10 One way to conceptualize "something else" is as a local statement of cultural interest in which foreign elements become distanced from their original source and take shape as something unique. ${ }^{11}$ Such concepts and practices "have to be localized in different ways" before they can fit into various complexes of religious, social, and political systems and belong "to new cultural "wholes." 12 Only upon the successful adaptation of the foreign idea would the fragments be embraced and understood by the people.

In addition, as Arnd Schneider asserts, we need to focus on the "hermeneutic process of appropriation, which means 'a taking out of one context and putting in another." 13 This process implies that cultural elements "are invested with new signification."14 Cultural Anthropologist Arjun Appadurai supports this theory by stating that as "rapidly as different forces from cultural and economic centers are brought into new societies they tend to become indigenized in one or other way[s]."15 However, these cultural forms are not merely reproduced "but infused with new, locally determined meanings."16 Michel de Certeau asserts that the masses "always renegotiate the meanings offered them," which allowed the rulers or ruling class of the society that localized the foreign concept to proclaim the uniqueness of the localized form. ${ }^{17}$ Thus localization is the practice of cultural borrowings transformed to fit unique historical, geographic, and religious contexts.

To use a Southeast Asian example, Indian customs and practices tended to be fractured, restated, and "drained of their original significance by a process of localization," which was particularly evident in Cambodia where Indian 
religions such as Hinduism and Theravada Buddhism developed into localized Cambodian variants. ${ }^{18}$ The Hinduized Angkor temples that the Khmer rulers had originally built as monuments devoted to the Hindu god Vishnu became Theravada Buddhist sites. In only a few centuries, the Indian influence on Cambodian society was localized to form something recognized as a uniquely Cambodian form. Extant ideas, rites, and practices ultimately joined with exogenous influences to become something that became particular to a region, culture, or people.

Indeed, Mao Zedong's "Sinification" of Marxism provides us with a recent example of a process whereby endogenous ideas blended with foreign concepts to create a localized form within a particular context. The "Sinification" of Marxism was Mao's attempt to adapt the universality of Marxism to China's particular national and cultural forms. The problem was that many Chinese intellectuals viewed Marxism as "a foreign dogma that was hostile to the essence of Chinese culture," thus making its widespread acceptance an enormous obstacle. ${ }^{19}$ To counter, Mao's qualification of Friedrich Engels' formulation of historical materialism "suggested that an ideology which has its roots in social, economic and political circumstances vastly different from those that existed in China must be modified if it was to serve as templates and guides to actions." 20 Mao's own modification of this existing Marxist formula was the first major step towards localizing Marxist ideology to suit China's historical context.

The next important step was Mao's proposal in 1938 for the "Sinification of Marxism," which referred to the specific ways in which the foreign theory of Marxism-Leninism could be adapted to the concrete historical realities of modern China. ${ }^{21}$ These "realities," as Raymond Wylie notes, included the under-development of capitalism, the absence of a large urban proletariat, and the central role of the rural peasantry. ${ }^{22} \mathrm{He}$ quotes Mao as stating that "[i]n the first stage of this complex process of interaction, new Marxist contents will fuse with traditional national forms, but the process will not terminate at this point but will instead progress to a second stage in which the interaction of content and form will transform the traditional forms into modern forms." 23 The final product, Mao states, will be a "distinctive culture that represents the total integration of modern Marxist (scientific) contents and modern national forms." 24 In so doing, Mao implemented "a strong ethos" and "a clear sense of a separate Chinese identity" to domesticate, militarize, and nationalize revolution in China. ${ }^{25}$

An important approach to the problem of ideas across cultures arises from the scholarly debate over the formulation of "Chinese" Marxism, or Marxism that was adaptable to China's environment. Central to this debate are efforts to identify Chinese Marxism as ideological continuity or divergence, 
orthodoxy or heterodoxy. As historian Nick Knight's scholarship has shown, Western analyses of Mao's Marxism cluster around three particular lines of thinking: one that foregrounds the primacy of Chinese nationalism in Mao's application; another that places power and legitimacy as the key factors; and Knight's position that regards Mao as a serious Marxist internationalist.

Proponents of the first argument such as Stuart Schram hold that Mao's belief in the "infinite capacity of subjective factors to change objective reality" rather than economic determinism broke with the very essence of Marxism. ${ }^{26}$ Schram asserts that Mao's nationalism and his emphasis on human will were antithetical to Marxism since he stressed the national over the international, and de-centered the development of the productive forces as the motive force for social change. ${ }^{27}$ But while these scholars are correct to address Mao's nationalism, the Chinese leader's own writings give no indication that he raised China above the internationalist struggle against capitalism and imperialism. ${ }^{28}$ As Paul Healy shows, for example, Mao's voluntarism did not depart from Marxist orthodoxy, and charges that the Great Leap Forward and Cultural Revolution represent "utopian orgies" ignore that Mao's underlying theoretical basis was "consistent with the fundamental tenets of orthodox Marxism's conception of social formation." 29 Knight continues the criticism of this first line by arguing that the stress on the Chinese influences on Li Dazhao and Mao betrays an "Orientalist assumption" that Chinese nationalism made any form of Marxism in China heterodox. ${ }^{30}$ In fact, Marx and Engels recognized that the Revolutions of 1848 throughout Europe were bourgeois-democratic and nationalist, and a close analysis of Chinese Marxists' written texts reveals their careful attention to Marxist orthodoxy. ${ }^{31}$ Therefore, to suggest that "Chinese intellectuals and philosophers who converted to Marxism could not possibly have understood Marxism" because it "grew out of the European intellectual tradition... thus posit[ing] 'being Chinese' as an insuperable barrier to the understanding of a theoretical system that originated outside the Chinese cultural hemisphere," holds little weight. ${ }^{32}$

A second line supported by Raymond F. Wylie positions power and legitimacy as Mao's ultimate goals. Wylie claims that Mao's political secretary Chen Boda was "the single most important figure... in helping to formulate and propagate the concept of Mao Tse-tung thought," which was central to the establishment of MaO as the predominant leader within the CCP and provided legitimacy for his thought. ${ }^{33}$ Mao's Sinification of Marxism therefore "emerged and developed in the context of a fierce struggle for supreme power in the CCP between Mao and the Returned Students."34 Although Chen's "sufficient yet culturally rooted understanding of Marx... enable[d him] to develop Mao's Marxism into a persuasive Chinese ideology," Sinification was, in Wylie's view, an ideological power play that Mao and Chen used in their dire struggle for legitimacy within the Party. 35 
A somewhat related position comes forward from Cold War historians Karl Wittfogel and Robert North, who state that Mao Zedong was primarily interested in applying a Soviet model to China's unique historical context. ${ }^{36}$ Their assertion appears tenable given the CCP's close relationship with the Soviets and their participation in the Comintern. ${ }^{37}$ As Meisner states, however, the relationship between Stalin and Mao was very tense from as early as 1927 since Mao's meteoric rise to atop the Communist Party hierarchy came "in direct conflict with CCP factions backed by Stalin."38 Lee Feigon supports this claim, stating that Mao realized that "he had made a mistake in trying to follow a Soviet model for China" and spent "two decades of his life trying to tear China away from the Soviet road." 39 Mao broke with the "consensus politics of the Stalinists" to weaken the heavily bureaucratic Party, which the pro-Russian Returned Scholars used as a device to dictate the CCP's direction. ${ }^{40}$

A third line of interpretation argued by Nick Knight, by contrast, returns the focus to the continuity of ideas, thereby taking Mao's devotion to orthodox Marxism seriously. ${ }^{41}$ Knight argues that Mao attempted to "establish a formula by which a universal theory such as Marxism could be utilized in a particular national context and culture without abandoning the universality of that theo$r y . ' 42$ But how does this argument account for the obvious process of localizing Marxism within China? Arif Dirlik asserts that Maoism represents less of an orthodoxy per se, and more of "a local or vernacular version of a universal Marxism [that] was very much a product of the globalization of Marxism outside Europe."43 Mao's Sinification was thus not a question of elevating Chinese peculiarities above Marxian universals or the other way around, although Mao's nationalism as well as his internationalism are certainly apparent in "On New Democracy." Rather, Mao's Marxism was an ideological endpoint; it was the step toward becoming a complete ideology where the particular (China) worked in concert with the universal (Marxism). Thus, Sinification represents a naturalization, or localization, of Marxism in a particular setting. 44

In summation, Mao Zedong created a formula by which the universal theory of Marxism was applicable in a particular national context without the abandonment of the universality of Marxian theory. ${ }^{45}$ The marriage of universal Marxian laws to particular laws that described China's unique characteristics created a genuinely Chinese Marxism. ${ }^{46}$ As we will see in the case of Peru's Shining Path, the union of a universal ideology with unique national characteristics breathed life into a revolution that lacked a support base and a military strategy to put its revolution in motion. ${ }^{47}$ 


\section{"PanchamaMAO:"48 The Shining Path and the Localization of Maoism in Peru}

On 18 May 1980, Peru held elections for a civilian President after twelve years of military rule. Just the day before, five masked members of the Communist Party of Peru-Shining Path set fire to ballot boxes in the Ayachuco village of Chuschi. ${ }^{49}$ Who were these masked revolutionaries? What was their message and purpose for such a surreptitious operation? The Communist Party of PeruShining Path, referred to hereafter as the Shining Path or Sendero for short, adopted Mao Zedong Thought as the Party's guiding ideology and launched a full-fledged socialist revolution. The Chinese Communist Party defined pre-revolution China with terms such as "semi-feudal" and "semi-colonial," which resonated with Latin American Marxists who regarded Latin America as sharing the same fate. ${ }^{50}$ The perception that the Chinese revolution contained "lessons" for Latin American societies led intellectuals such as Shining Path founder Abimael Guzman Reynoso to embark on a patronage to Beijing where he studied Mao's works and trained in the military art of people's war. ${ }^{51}$ Mao's principle of people's war provided the Shining Path with a way of fighting and a way of life that embodied "a vision of man and society and an approach to development built on foundations of popular participation and egalitarian values." 52 By the 1980s, the Shining Path consolidated itself as a Maoist organization and launched a protracted struggle that aimed—and almost succeeded—at toppling the Alberto Fujimori government in Lima.

By no means is this paper trying to exonerate the Shining Path for their uses of violence and drug trafficking during and after the revolutionary struggle. Rather, the present study adopts scholarly neutrality to evaluate its case objectively. More recently, scholars have cast the Shining Path in a negative light for its use of terrorism, betrayal, illegal transnational cocaine trade, murder, and for allegedly betraying their peasant/indigenous constituency during the waning years of the People's War. However, these same scholars fall into a temporal trap by foregrounding these later more radicalized methods at the expense of giving due attention to Sendero's earlier policies of indigenous outreach. Seldom have scholars explored the much more compelling ways in which the Shining Path attained indigenous support through the appropriation of Jose Mariátegui's indigenismo policy of the 1920s and the evocation of Incan legends, culture, and history. ${ }^{53}$ Sendero tried to base its revolution organically and on unique local conditions. For these reasons, the section examines the ways in which the Shining Path created a synthesis of Maoist precepts with Marategui's Peruvian socialism and Andean cultural norms.

Before exploring the Shining Path's localization, we must investigate the present scholarly arguments in the field of contemporary Peruvian history. Historians such as Olin Starn, Carlos Degregori, Robin Kirk, and Daniel 
Masterson assert that the Shining Path never truly reached out to the indigenous population. Among those few who argue otherwise, they also posit that the Shining Path betrayed the Andean peoples through top-down elitist treatment of indios and, in cases, violence directed against their indigenous followers. Starn, Degregori, and Kirk argue that the Shining Path's class-based ideology "is notable for a complete absence of appeals to 'Indian' or 'Andean' pride." 54 In fact, Starn argues that the Shining Path's ideology "eschewed completely any appeal to 'indigenous' or 'Andean' roots" while the Party's political culture focused almost exclusively on class struggle, anti-imperialism, and on the Party's primacy in revolution. ${ }^{55}$

The same scholars also argue that the Shining Path "failed to build broad support among Peru's poor majorities" since their radical people's war in mountainous Ayachuco went down as "a gripping, yet historically doomed anachronism." 56 Degregori argues that the Shining Path's relationship with Peru's peasants was particularly ambiguous since the party took "a top down approach" to their treatment of peasant and indigenous recruits. ${ }^{57}$ The Shining Path insisted that the Party had to serve the masses and bring them harmony, but had to "educate them and coerce them into support when necessary."58 Alex Cook, meanwhile, asserts that the Shining Path "was supposed to be a creative acclimatization of Marxism to the Andean highlands," but instead "assimilated many of the same feudal and colonial social divides it had intended to destroy." 59 Nowhere is this more evident in the Shining Path's forcibly imposed "war planting schedule upon the villagers" and its serious disruption of their intricate agricultural cycle. $^{60}$ Thus as Degregori argues, Sendero was primarily a movement of intellectuals, left-of-center activists, and disillusioned Peruvian youths. ${ }^{61}$

In the same vein, historian Daniel Masterson asserts that the Shining Path was "never a peasant-based insurgency" since the "strategic equilibrium" that Sendero Luminoso $0^{62}$ hoped to achieve in the countryside "was never achieved because of the insurgency's misunderstanding and terrible abuse of the peasantry." 63 The Party's shift of the anti-government campaign to Peru's capital and largest urban center in Lima alienated much of the Shining Path leadership and "broke with Maoist principles." 64 Starn, meanwhile, argues that the gradual government withdrawal from the countryside "meant a cut off of modest outside support for projects like clinics, schools, and small irrigation projects." 65 Such led to the emergence of peasant self-defense brigades known as Rondas Campesinas. ${ }^{66}$ As Peru's peasantry felt alienated and wanted to distance themselves from the radical Maoist movement due to the insurgency's destruction of Peru's rural infrastructure, many peasants organized into defense brigades to ward off Shining Path members from entering the villages. ${ }^{67}$

Yet these scholars do not offer enough evidence to challenge the argu- 
ment that the Shining Path's ideology resonated with groups of indigenous peoples. Instead, anti-localization scholars rely on various Truth and Reconciliation Commission tropes to foreground the later period, which makes Sendero's radicalization, excessive violence, and drug trade stand in for their earlier policies of indigenous outreach. ${ }^{68}$ The Shining Path's appropriation of Peruvian Marxist Jose Carlos Mariátegui's ideology of indigenismo and the subsequent synthesis of Maoist precepts with Incan cultural forms and traditions must receive due attention since these policies did resonate with indigenous peoples. Rather than rely on evidence forged around a temporal slippage, we must examine the ways in which Peru's marginalized Andean peoples regarded these two "uniquely Peruvian" concepts as essential parts of a new Peru that could one day improve their standard of living.

Due to the Peruvian state's concerted effort to eradicate the "ethnic question" and its effort to turn its indigenous population into peasants, Peru's indigenous peoples had yet to form a strong national movement. ${ }^{69}$ The Shining Path presented a new face to Peru's political culture that encouraged indigenous peoples to reject the subordinate status imposed on them for centuries. ${ }^{70}$ The Ayachuco peasants embraced Guzman's version of Mariátegui's indigenismo and began to enlist members from various communities to fight for their cause.

In order to grasp the complexity of the Shining Path's localization, something must be said of Jose Carlos Mariátegui. In the late 1920s, Mariátegui, described as one of the "few original Marxist theoreticians Latin America has ever produced," established the Socialist Party of Peru. ${ }^{71}$ Mariátegui recognized that Peru was a plagued country that suffered from semi-feudal and semi-colonial subordination at the same time. ${ }^{72}$ While Marxian theory alienated world peasantries due to its focus on industrial sectors, Mariátegui centered his ideas on the "reality of Peruvian poverty, race, class conflict, and neo-colonialism." $73 \mathrm{He}$ strongly believed that Peru offered a unique and interesting model for a groundbreaking form of Latin American socialism. ${ }^{74}$ As Masterson notes, Mariátegui identified in the "reciprocal communalism of Andean social tradition" a form of "communism." 75 His communism was a great improvement over the highly "exploitative, individualistic, and foreign-dominated policies" that marginalized the indigenous peoples and stripped Peru of its burgeoning potential as a continental economic force. ${ }^{76}$ Mariátegui thus saw the solution to Peru's semi-feudal and semi-colonial subjugation in the application of traditional Andean social models to a contemporary socialist Peruvian state. ${ }^{77}$

One of the keys to understanding the importance of Mariátegui's indigenismo and further contributions to modern Peruvian socialism" 78 is to "recognize his unique willingness to use traditional Andean social norms as a workable model" for Peru's current historical contexts. ${ }^{79}$ The Peruvian Marxist asserted 
that traditional models of Andean socialism could be applied to modern contexts "if an efficient educational system emphasizing primary schooling for the masses, technical training, and a free and accessible university system was established as a foundation." 80 However, Mariátegui was not implying that Quechua ${ }^{81}$ Indian society required westernization of any sort. Rather, he argued that the ayllu — a system of production and community that dates back to Incan timespreserves two great economic and social principles: to "contract workers collectively and to have the work performed in a relaxed and pleasant atmosphere of friendly competition." 82 Unfortunately, Mariátegui's uniquely Peruvian innovation led to his dismissal from the Comintern conference in 1929, and he died soon afterward. ${ }^{83}$

Despite his political ex-communication and premature death, what are most important here are the ideas that Mariátegui set in motion. According to historian Lewis Taylor, Mao's concept of semi-feudal and semi-colonial society proved "highly compatible with Mariátegui's description of Peru in the first half of the twentieth century, with multiple coexisting worlds: indigenous peasant communities practicing primitive agrarian communism, colonial-era haciendas maintaining a feudal economy in the highlands, semi-feudal coastal estates producing crops for export, and bourgeois urbanites with ties to international capitalism." 84 Abimael Guzman Reynoso, the future head of the Shining Path, explained in an interview that the more he read Mao Zedong's works, the more he began to see Jose Carlos Mariátegui as a "first rate Marxist-Leninist who had thoroughly analyzed our [Peruvian] society." 85 Mariátegui's focus on forming a rural base from which to launch a revolution against the forces that prevented the advancement of Peru's indigenous peoples became central to the formation of the Communist Party of Peru-Shining Path in the 1970s. It was not surprising, then, that Guzman appropriated Jose Mariátegui, a man who spoke out in favor of improving the standard of living of the Andean peoples, and reconciled his own fascination with Maoism to create a unique "sword of Marxism Leninism." Mariátegui ultimately provided the Shining Path with an analysis of Peru's society while Mao Zedong "provided the strategy to change it."86

In 1970, a philosophy professor at the National University of San Cristobal de Huamanga in Ayachuco, Peru named Abimael Guzman Reynoso founded the "Shining Path" — a direct linguistic borrowing from Mariátegui's coining of the term "the Shining Path to the future" in reference to Marxism. ${ }^{87}$ According to historian Olin Starn, Guzman arrived in Huamanga in 1962 from middle-class origins in the town of Mollendo. ${ }^{88}$ Starn describes him as a "reserved yet self-confident man" who donned the Andean dress. ${ }^{89}$ During the mid 1960s, Guzman became an admirer of Mao Zedong, toured China during the later years of Mao's Great Proletarian Cultural Revolution, and received small arms training at a Chinese cadre school. ${ }^{90}$ The Shining Path under Guzman's 
leadership broke from the Communist Party of Peru and embraced many of Mao's ideas, such as people's war, self-reliance, Third World anti-imperialism, and the Cultural Revolution. ${ }^{91}$ These influences led Guzman to exclaim that the Shining Path's armed struggle required the mobilization of the peasants "under the infallible banners of Marxist-Leninist-Mao Zedong Thought." 92 Furthermore, Guzman's choice of Ayachuco as a base from which to launch the people's war revolution mirrors Mao's base in the remote Chingkanshan Mountains where he fought three successive revolutionary civil wars against Generalissimo Chiang Kai-Shek. ${ }^{93}$

As Guzman's influence at the university waned, the Shining Path set up "popular schools" to "increase class-consciousness among the peasantry, working class, and students." "94 Guzman and his disciples highlighted the Peruvian state's corruption, its numerous failures and shortcomings, and Mariátegui's creative Marxist analysis of Peruvian society. ${ }^{95}$ According to historians Michael Arena and Bruce Arrigo, the "popular schools" emphasized the "need for class struggle, the incompetence of parliamentary democracy... [and] the Shining Path's plan for securing New Democracy." 96 Within a short period, Guzman gained a multifarious support base of former students and local peasants in the impoverished Ayachuco region and declared a war against Peru's wealthy bourgeoisie. ${ }^{97}$ By the 1980s, the people's war had begun.

The Shining Path entered the first stage of Maoist revolution-agitation and propaganda - in late 1970. In true Maoist fashion, the Shining Path constructed their vanguard base on the backs of the country's peasantry. ${ }^{98}$ The Shining Path called for a peasant rebellion against Peru's large landowners for oppressive policies that since the 1800 s marginalized the Peruvian indigenous peoples. ${ }^{99}$ With the election of Fernando Belaunde Terry in the early 1980s, newly reformed agricultural policies betrayed most of the country's agronomists in the southern highlands. ${ }^{100}$ The Shining Path saw an opportunity to appeal to the victimized "Indian" and wedded the suffering of the indigenous people to the Party's revolutionary program, guerrilla army, and the new state they hoped to establish in Lima after the successful fifth stage of Maoist revolution. ${ }^{101}$

The Andean peasants relied heavily on the notion of reciprocal economic justice and identified with the Shining Path because its operations "acted as a reflection, and an expression, of their own social and economic frustrations." 102 City dwellers paid very little for agricultural work and wealthy peasants did not make significant labor contributions. Thus, many peasants vehemently resented the upper classes. Through his use of respondent data from the Ayachuco region, historian Ronald Berg cogently argues that there was "considerable support" for killing the mostly-mestizo ${ }^{103}$ Peruvian wealthy. ${ }^{104}$ As a number of Andean peasants stated, "I have nothing against their killing the rich (los 
ricos)... I don't like it when they kill peasants (campesinos)."105 One sympathizer stated that the men the Party killed "deserved what they got because they were rich, had two or three houses, and had acquired their wealth through unfair exchange."106 Support for the Shining Path grew because the peasants and indigenous peoples believed that the party understood their aspirations, such as their desire to possess a measure of autonomy at the local level and the right to practice subsistence agriculture through land ownership. ${ }^{107}$ As Berg elucidates, peasants held animosity toward Peru's wealthy and bought into the Shining Path's social program of improving indigenous rights.

Most importantly, the Shining Path exploited the cultural significance of Incan myths and Andean symbolism to broaden its revolutionary support base. ${ }^{108}$ The Shining Path espoused elements of Quechua Indian culture, which historian Stefano Varese states "became increasingly evident" in the Party's activities. ${ }^{109}$ The most culturally significant myth was that of Inkarri, which recalls a sixteenth century event where the Spanish colonizers dismembered, scattered, and buried the body of the last Incan sovereign Tupac Amaru I. ${ }^{110}$ According to Arena and Arrigo, the Shining Path represented its leader Abimael Guzman as "the modern day incarnation of the Inkarri."111 Sendero posters portrayed Guzman at the center "dressed in a suit, wearing glasses, [Mao's red] book in hand, surrounded by masses carrying rifles and flags, with the great red sun setting behind him." 112 Since Andean mythology held that the rise of the red sun meant the return of Inkarri, the Shining Path's Indian followers gave Guzman the Quechua title of "Red Sun:" pukainti. ${ }^{113}$ The Shining Path's Andean followers revered their new "Inca king" with "God-Sun adoration" and entrusted his Party to bring the impoverished descendants of the great Incans to a more prosperous and respectful future. ${ }^{114}$

Another weapon for widespread support was the evocation of Andean symbolism. The Spanish celebrated the execution of Tupac Amaru I and placed his head on a stake to discourage further indigenous uprisings. The Shining Path argued that Tupac Amaru's body, which stood as the quintessential Incan symbol for the dispersal of Indian tribes and the reverence of Incan cultural heroes, was slowly reconnecting in the forms of the Peruvian clandestine movements. As Varese, Arena, and Arrigo state, the Andean peoples believed that only when the desecrated head of Tupac Amaru I rejoins the rest of the body or grows its new body underground will the Inca nation rise up and obtain its pre-Columbian state of independence. ${ }^{115}$

In addition, the Shining Path revolutionaries emphasized the 199 th anniversary of the Spanish execution of the Quechua Incan rebel Jose Gabriel Condorcanqui, immortalized in Incan legend as "Tupac Amaru II."116 In the eighteenth century, Condorcanqui launched a bloody anti-colonial revolution. 
The victorious Spanish captured Condorcanqui and sentenced him to death in the same brutal manner that the Spanish had killed Tupac Amaru I centuries before. Thus, according to Varese, the Andean tradition "unites symbolically all other Indian revolutionary heroes, such as Tupac Amaru I (16 $6^{\text {th }}$ century) and Tupac Amaru II (18 $8^{\text {th }}$ century)." 117 After all, the Spanish ensured that the two indigenous leaders suffered the exact same symbolic fate of gruesome public dismemberment and disjointed burial across Peru's highlands. The Shining Path promised that only when all the indigenous peoples of Peru lent their support to Pukainti and his Shining Path movement shall Peru's "cosmic race" obtain their long sought after salvation. ${ }^{118}$ Ultimately, the Shining Path's appropriation of indigenous cultural and traditional norms positioned the guerrilla organization in place to use "ethnic survival" as part of its aggressive recruitment strategies. ${ }^{119}$ To summarize briefly the events that followed, the Shining Path completed the second, ${ }^{120}$ third, ${ }^{121}$ and fourth ${ }^{122}$ stages of Maoist revolution between 1980 and 1988. ${ }^{123}$ The people's war expanded, and by 1989, the guerrillas prepared to launch the people's war on Lima. ${ }^{124}$ However, the fifth and final stage that entailed the fall of the cities was never achieved. Nevertheless, the Shining Path succeeded in launching "the largest insurgency on Peruvian soil since the Tupac Amaru II rebellion two centuries before."125 The Truth and Reconciliation Commission noted that the armed conflict between 1980 and 2000 "constituted the most intense, extensive and prolonged episode of violence in the entire history of the Republic."126 As the people's war raged on, the Shining Path radicalized increasingly and launched brutal internal purges to ensure longevity and loyalty. Abimael Guzman, now named "Presidente Gonzalo,"127 took advantage of his personality cult status and taught his five thousand armed guerrillas that the Russians, Cubans, the Chinese, and North Koreans were "weak and not true Communists."128 The Shining Path's official party ideology ceased to be "Marxism-Leninism-Maoism," and instead became "Marxism-Leninism-Maoism-Gonzalo thought."129 But Peruvian forces captured the "great teacher" in 1992 and sentenced him to life imprisonment. Although the People's War continued in an ever-degenerating state, Abimael "Presidente Gonzalo" Guzman's incarceration and subsequent official statement from prison effectively ended the Maoist revolution in Peru. ${ }^{130}$

These later developments have wrongfully been the focus of contemporary scholars on Sendero. While one cannot deny that the Shining Path was a violent and radical revolutionary movement, the Party succeeded in "localizing" Maoism and breathed life into Mariátegui's indigenismo. Whether historians classify Sendero as terrorists, revolutionaries, or freedom fighters, the Shining Path challenged the corrupt and anti-indigenismo Peruvian state and exposed the limits of Peruvian agency. The Shining Path's earlier devotion to indigenous activism and 
social reform must not be shrouded by their later extremism and controversial methods. In the end, Sendero succeeded in its mission to plant the seeds of Maoism in the Andes Mountains and watched it grow into a uniquely Peruvian form of socialism.

\section{The Counter-Example: Mwalimu and Ujamaa Villagization}

In 1961, British rule in Tanganyika ended in a bloodless transition of power. Julius Nyerere led his fledgling TANU to victory in the nation's first democratic elections. Shortly after Nyerere took office, he formed a special relationship ${ }^{131}$ with the People's Republic of China and visited Beijing. ${ }^{132}$ Maoist cadres soon flooded the now-Tanzanian ${ }^{133}$ countryside and tirelessly promoted Mao Zedong Thought to African workers on the TANZARA ${ }^{134}$ railway. ${ }^{135}$ Yet Nyerere insisted upon the creation of a uniquely "African" socialism for his new nation. According to historian May Joseph, Nyerere's socialism was predicated on "a conscious anti-colonialist move to delink from the West's imperial obsessions" through which Tanzania "would create its own autonomy as a nation-state."136 More specifically, Nyerere's national development project known as ujamaa aimed to transcend all existing social divisions in Tanzania. Yet ujamaa ended in disaster; the development program failed to increase productivity and merely reproduced many of the social divides it intended to eradicate. ${ }^{137}$

This section examines the Tanzanian case as a counter example to Peru's Shining Path movement. According to historian Goran Hyden, Nyerere regarded ujamaa as an "attempt to base development efforts on an indigenous base instead of borrowing models and ideas from outside."138 The section analyzes what Nyerere thought he was doing for his people with his invented African traditions and evaluates the debates on ujamaa by social democrat Cranford Pratt, Marxist scholars Issa Shivji and P.L. Raikes, political scientist Leander Schneider, and post-colonialists Goran Hyden, Jean Francois Bayart, and Michael Schatzberg. ${ }^{139}$ The section then channels Abdul Rahman Babu's critique of African socialism to present Maoism—an oft-overlooked ideology given its emphasis on politicization - as an alternative framework and examines the ways in which Maoist precepts offer an insightful analysis to many of the socio-political detriments that plagued Tanzania during ujamaa villagization.

Before delving into the various analyses that are pertinent to this study, one must first examine the reasons why Maoism became a peripheral ideology in an independent Tanzania. Maoism was ever-present in Tanzanian society. Chinese supervisors expected Tanzanian laborers to be inspired by Mao, "to be determined, be afraid of no sacrifices, to reject all difficulties and to achieve total victory." 140 Historian Jamie Monson states that his colleague, Kim Jaycox, remembered that at the Chinese restaurant on the rooftop of the New Africa Hotel in Dar es Salaam, Chinese cadres distributed Mao's teachings and Mao 
buttons freely, and that "the back streets were filled with revolutionaries."141 In addition, Chinese-trained Tanzanian university students offered instruction in small arms, explosives, and people's war guerrilla tactics to movements outside Tanzania, namely the FRELIMO movement in Mozambique. ${ }^{142}$

So why did Nyerere and the TANU reject Maoism as an ideology in favour of invented "African" traditions? The TANU marginalized Maoism for two reasons. First, Nyerere was happily non-aligned and identified more with Fabian socialism and Catholic social teachings than any radical dogma. ${ }^{143}$ Nyerere was a Christian and was raised and educated in the Western democratic tradition. ${ }^{144}$ Furthermore, historians Bonnie Ibhawoh and J. Dibua assert that Nyerere's ideology fused European concepts derived from Kantian liberalism with an ethos inspired by his idealized communitarian native African society. ${ }^{145}$ Nyerere never wanted to sacrifice the ethic of individualism and firmly believed in the people's right to elect their own representatives. ${ }^{146}$ Second, Nyerere's major government officials were, for the most part, anti-communist and antidogmatic. Prime Minister Rashidi Mfaume Kawawa, Vice President Abeid Amani Karume, Junior Minister R. Wambura, and Foreign Affairs and Defense minister Oscar Kambona were all statists that rejected any form of ideological extremism. In fact, Kambona initially opposed ujamaa villagization in favor of a more pragmatic approach. ${ }^{147}$ In sum, these factors caused Maoism to become peripheral in Nyerere's and the TANU's ideological pursuits.

In order to grasp the complexity of the scholarly debates on ujamaa, something must be said about Nyerere's vision for rural development in Tanzania. Following Nyerere's 5 February 1967 Arusha Declaration, ${ }^{148}$ the Tanzanian government put in motion its President's "African" socialist rural development plan. ${ }^{149}$ Although villagization began in the early 1960s as part of a strategy to break Tanganyikan dependency on Britain, total collectivization did not begin until Nyerere published "Socialism and Rural Development."150 Nyerere based his vision for socio-economic reorganization on his idealized perception of traditional pre-colonial African family life, which he named ujamaa for "extended family." 151 Central features of the ujamaa communes were mutual respect, shared property, obligatory labor, and self-reliance. ${ }^{152}$ Nyerere stated that in traditional African life "the people were equal, they cooperated together, and they participated in all the decisions which affected their lives."153 However, it must be stressed here that Nyerere's idea of pre-colonial African society was an invented tradition that merely drew inspiration from ideas of traditional life and not actualized traditional methods. ${ }^{154}$ He merely constructed an idyllic "African essence" which he marketed to his people as tradition.

The Arusha Declaration outlined the ways in which this new "traditionally inspired" system would come to "dominate the rural economy and set the 
social pattern for the country as a whole." 155 As Elisabeth Croll states, in an ujamaa village system "all but the individual household plot is farmed communally." 156 Even though this system was one of "shared poverty," Nyerere aspired to modernize the traditional ujamaa structure to suit the country's

demand for a vastly improved standard of living. ${ }^{157}$

To accomplish this end, the Tanzanian President encouraged his people to form economic and social communities "where people live together and work together for the good of all, and which are interlocked so that all of the different communities also work together in cooperation for the common good of the nation as a whole."158 Nyerere also wanted to provide more accessible government services such as schools, medical services, water, agricultural officers, and transport facilities to Tanzania's rural peoples in addition to increasing agricultural production. ${ }^{159}$ While Nyerere believed that ujamaa cooperative villages would break the colonial era "dependency" trend of the production of export crops, there remains a considerable debate on whether ujamaa succeeded in improving the peasants' standard of living and breaking Tanzania's dependency lifeline on foreign sources. ${ }^{160}$

Social democratic historian Cranford Pratt supports what Nyerere thought he was doing in Tanzania with ujamaa villagization. ${ }^{161}$ Pratt posits that any assessment of Nyerere's socialism must recognize his commitments to Tanzanian economic development, national control, participatory democracy, and equality. ${ }^{162}$ Pratt provides four reasons to support Nyerere's Tanzanian socialism. First, Pratt endorses Nyerere's moral concern over the techniques used to achieve a "unique" socialism. Pratt argues that Nyerere implemented leadership rules to "provide a modern and relevant application" of perceived traditional African values while seeking to exalt equality and root out colonial era social distinctions. ${ }^{163}$ Second, Nyerere devoted himself to socialist ideals without revolution, a military coup, or electoral victory. Third, Nyerere attempted to develop this socialism along egalitarian, socialist, and democratic lines. According to Pratt, Nyerere "chose socialism" primarily because it was in Tanzania's "best interest to pursue development along socialist lines."164 Pratt asserts that by stressing individual liberty, Nyerere succeeded in eliminating the gulf between the rural peasants, urban working class, and government elite. ${ }^{165}$ In essence, Nyerere knew that the country "would long be poor and that the building of a just society would become vastly more difficult if ever class differences were entrenched."166 Fourth, Nyerere's socialist ideology is genuinely indigenous and not an adaptation of a foreign dogma. Pratt lauds Nyerere's qualities, such as his nationalism, opposition to African oppression, and anti-dogmatism, as vehicles that led him to find a workable alternative to the industrialized states" "neo-liberal policies." 167

In contrast, Marxists Issa Shivji and P.L. Raikes contest Pratt's asser- 
tions through analyses of Africa based upon Western capitalism and its development from European feudalism. ${ }^{168}$ While Pratt is correct to state that no classical class divisions ever existed at the national level, Shivji argues that the system of social production in Africa is an essential cog in the world capitalist scheme. ${ }^{169}$ He posits that capitalism has taken on a completely different form in Africa, which negatively affected the formation of the rural peasantry. ${ }^{170} \mathrm{He}$ states that the introduction of "cash crops" to Tanganyika "set in motion the process of differentiation within the peasantry." 171 Although some peasants protected their interests by "fraternizing with the bureaucracy," internal and external dominating classes took advantage and exploited the poor peasants. ${ }^{172}$ Because of this dual domination, the worker-peasant alliance emerges from "an analysis of both the working class and poor peasantry in relation to other classes, from their role in social production, and their objective interests in conflict with imperialism and its local class allies." 173 These already entrenched class differences, struggles, and alliances "require indispensably a political organization" based on a proletarian class-consciousness, which Pratt argues, does not exist. ${ }^{174}$

In the same vein, Raikes asserts that Tanzania "is a class society" since the "bureaucratic bourgeoisie" 175 is and has been entrenched since independence. ${ }^{176}$ Nyerere intended his development plan to be a "strategy of disengagement from the world capitalist system" since a state that failed to nourish its populace was powerless, dependent, and "potentially vulnerable to the dictates of others." 177 However, nationalized ujamaa property fell into "the jaws of a deeply venal class of vibwanyenye," a Swahili term for the bourgeoisie. ${ }^{178}$ This same bourgeoisie that administered Tanzania's affairs also "distrusted the peasants' intentions and capabilities" since democratically controlled ujamaa villages posed "a real threat to their status" and "threaten[ed] their control."179 Hyden supports this claim, arguing that the petty-bourgeoisie in Africa "is clearly anxious, like any other class, to create a power base of its own and defend it."180 Therefore, Tanzania's ujamaa policies must be regarded as a concerted effort on behalf of the ruling class to protect their high-class status.

In opposition, Marxist readings of ujamaa that lambaste the bureaucratic bourgeoisie fail to recognize the antagonistic relationship between the peasantry and other classes. ${ }^{181}$ As Hyden notes, African peasants are self-sufficient and have considerable control over the means of agricultural production. ${ }^{182}$ Due to their near-total disconnection from the core, the bureaucratic bourgeoisie's dependence on peasant production causes its members to focus on the acquisition of outside capital to reverse the relationship of dependency. Ujamaa failed, in Hyden's view, because the peasant mode of production was "far too narrow for a rapid socialist transformation." Thus peasants became "unwilling and unable" in their insurmountable struggle to meet the demands of capitalism. ${ }^{183}$ 
Political scientist Leander Schneider and historians Jean Francois Bayart and Michael Schatzberg emphasize vertical leadership, paternalism, and displays of excessive force. Schneider emphasizes the negative repercussions of the TANU's elitist attitude and use of compulsion- explored further later on in this section- when it forcefully relocated Tanzania's rural population. Despite arguing that ujamaa villagization was "throughout a well-intentioned policy," he states that the method of villagization "was coercive and top-down, and it is generally agreed that it did not improve the majority of rural Tanzanians' lot, as had been hoped." 184 Furthermore, the TANU's adoption of coercive methods "points to the authoritarian side of Nyerere's rule." 185 The use of persuasion, inducements, and compulsion to ensure the successful experimentation of ujamaa vijizini reveals the ways in which the TANU elites and state officials regarded the rural peoples as "backward, ignorant, and- in some instances- even 'savage." 186 In essence, the TANU's "developmentalist hierarchy" failed to raise the rural population's standard of living and widened the gulf between the "civilized us" and the "backwards them."

In addition, Bayart and Schatzberg emphasize the vertical nature of post-colony rule in Africa. Bayart's study focuses on African rulers' monopolization of resources, namely food. Bayart refers to post-colonial African politics as the "politics of the belly: the idea of accumulation, opening up possibilities of social mobility, nepotism, corruption, and other methods of dominance that allow the holder of power to 'set himself up."'187 Schatzberg refines Bayart's "politics of the belly" by arguing that the center's distribution of the resources serves as an important locus of their legitimacy as the "fatherchief." 188 Schatzberg posits that a "moral matrix of legitimate governance," which is fundamentally rooted in paternalistic/maternalistic rhetoric, propaganda, and metaphors, forms the basis of the "belly politics" of Bayart's groundbreaking study. ${ }^{189}$ For example, a Swahili poem praised Nyerere for being the "first person to respond to the needs of the people" and compared the nation to an "infant wishing to be breastfed."190 Even though Nyerere's "African" socialist ideology and hardworking personality seemed incompatible with such metaphorical imagery, the way he ruled Tanzania reflected his inner paternalism. ${ }^{191}$

The appreciation or depreciation of Nyerere's ujamaa ultimately depends on what aspect of the socio-economic policy scholars choose to highlight. Pratt's appreciation of Nyerere's ideas ignores the effects of its practice on the ground. Class divides existed and the feudal nature of the core-periphery relationship took the form of a semi-colonial and semi-feudal elite-peasant cleavage. However, strictly Marxist readings that lambaste the bureaucratic bourgeoisie tend to overlook the antagonistic relationship between the peasantry and other classes in Africa. ${ }^{192}$ The peasants' self-sufficiency and control over the means of subsistence resulted in the bureaucratic bourgeoisie's dependence on 
peasant production and, therefore, caused them to turn to outside capital to alleviate this constriction. ${ }^{193}$ This argument, however, fails to identify the paternalistic nature of rule in post-colonial Africa. Nyerere positioned himself as the "fatherchief" and his government adopted a "top-down" attitude towards the "national children," which was embodied in Tanzania's millions of peasants.

Despite their differences, these scholars agree that ijamaa was a complete and total failure. Yet it is bizarre that with this consensus over ujamaa's failings, Maoism is not drawn attention to as an insightful analysis to mete out the plagues of Nyerere's failed socio-economic program. Maoism was certainly pervasive enough to circulate throughout work sites and universities in Tanzania. Why have scholars devoted so little attention to Maoism in this regard? Is it due to its heavily politicized nature? This paper sheds light on Maoist precepts, namely Mao's notions of voluntarism, self-reliance, and a worker-peasant alliance - all central to Babu's critique of Nyerere in particular and African socialism in general —as serious insights to the socio-economic issues that ujamaa failed to extinguish. ${ }^{194}$

Mao Zedong's philosophical approach to Marxian analyses of society held practice, human experience, and human will as primaries. Mao placed "the superstructure" over "the base" as the "location of the motor of history."195 In particular, Mao's notion of voluntarism, which held human will at its core, inspired many willing participants during China's Great Leap Forward period. Contrary to Marxian theory, which came down firmly "on the side of economic determinism" through the emphasis of development as the cause of social change, Mao advocated that the "human factor" was truly the primary driver for such a transformation. ${ }^{196}$ Mao's theory of voluntarism, in particular, rather than Marx's premise of economic determinism in general, revealed the Chinese leader's dependence on a revolutionary spirit within his people. ${ }^{197}$ Mao's transformation of many of China's rural areas into communal places of life and work utilized a voluntaristic approach in which the peasants "were not alienated" but encouraged to "stride forward on their own."198 Mao thus created alternatives to old and corrupt institutions and eventually won the "voluntary enthusiastic support" of the vast majority of the Chinese people. 199

In the same vein, Schneider points out that Nyerere and the TANU initially regarded voluntarism, democratic principles, and local control as important "means to the end of the successful achievement of the material goals of development." 200 Nyerere acknowledged voluntarism and local power as important $\operatorname{cogs}$ in the moving wheels of ujamaa vijijini. ${ }^{201}$ However, the reach of such ideas was very limited. ${ }^{202}$ On the ground, the communalization efforts proved to be nothing more than a subterfuge for grouping peasants together to conveniently and cost-efficiently facilitate various social services through total collectivization, such as water, education, and seed distribution. ${ }^{203}$ Nyerere then launched 
"Operation Rufiji” and "Operation Dodoma" in 1970, both of which forcefully moved whole populations in those regions into planned villages if they refused to cooperate. ${ }^{204}$

The TANU's enforced settlement of the majority of Tanzania's rural population into seven thousand villages began in 1968 and the Party considered the program "complete" by 1975.205 By 1973, ujamaa villagization forced the resettlement of "seventy percent of the country's rural population to 'planned villages." 206 As production slowed and the peasantry wavered in its commitment, Nyerere launched "Operation Tanzania" later that year. The mass relocation plan, described by historian Kelly Askew as the "largest on the African continent," called for the relocation of the entire rural population in Tanzania to ijamaa villages. ${ }^{207}$ The program veered toward disaster near the end of 1975 , thus the TANU "severed the final thread with ideals of voluntarism" and embraced harsher forms of compulsion as methods to force the ujamaa plan along. ${ }^{208}$ TANU forces destroyed the houses and used excessive methods of compulsion to force ninety-one percent of Tanzania's peasantry into villages. ${ }^{209}$

In addition, Nyerere called on the people of Tanzania to "have great confidence in themselves" and to preserve Tanzania's autonomy. ${ }^{210}$ However, the Tanzanian President later stated that eventually, the people "will lose their enthusiasm and will look upon the independence government as simply another new ruler." 211 Furthermore, Nyerere asserts that the people "will then sink back into apathy - until the next time someone is able to convince them that their own efforts can lead to an improvement in their lives." 212 Nyerere's ujamaa villagization soldiered on in spite of heavy socio-economic costs. The end result was a massive increase in Tanzania's debt, strained relations between the urban and rural peoples, as well as between Tanzania and its international donors, and created a huge crisis in the country's balance of payment deficits to foreign contributors. It is for these reasons that an examination of the notion of self-reliance is particularly salient. ${ }^{213}$

During the anti-imperialist struggle against invading Japanese forces, Mao stated the importance of China's own national resources and its role as the fuel of the people's revolution. He asserted that China stood for self-reliance and that although the country "hope[d] for foreign aid [it] cannot be dependent on it, we depend on our own efforts, on the creative power of the whole army and the entire people."214 Mao wholeheartedly believed that China's policy should rest on its own strength, and that meant "regeneration through [its] own efforts." 215 As we can see, Mao believed that the workers, peasants, and working intellectuals created the wealth of a society. Furthermore, three of these important strata had to work collectively to provide for the revolution in its continuance while making use only of China's national resources. ${ }^{216}$ By relying on one's own strength, nations of the 
Third World could shed their dependency and reclaim the mandate to rule their own lands. ${ }^{217}$

In Tanzania, Nyerere promoted the notion of self-reliance as one of the major themes of the Tanzanian Arusha Declaration and ujamaa. Nyerere stressed the idea of self-reliance in the early 1960s, but he did not employ the term until June 1965, after Chinese Foreign Minister and Premier Zhou En-lai's visit to Dar es Salaam. ${ }^{218}$ The Nyerere Government also emphasized the many dangers of dependence on foreign aid and encouraged self-reliance as the only viable solution to Tanzania's socio-economic development. ${ }^{219}$ However, the TANU modified ujamaa to "conform closely [to] the preconceptions and interests of the bureaucratic bourgeoisie who controlled its implementation." 220 Nyerere encouraged no "class struggle against the internal and external classes with vested interests in maintaining and perpetuating the existing relations of production." Instead, many planned villages "were entirely integrated into the previous dependency pattern of production of export crops." 221 Rather than produce surpluses for the peasants, ujamaa villagization facilitated the strenuous production of surplus for capitalist buyers in the developed world.222 As a result, Nyerere's ujamaa never developed a full-fledged plan for the overall transformation of the economy. Thus, ujamaa reinserted Tanzania's peasant communities into the dependency economy of colonization and turned the rural peasant population into a massive production force for outsider wants and needs. ${ }^{223}$

As for Mao's notion of a worker-peasant alliance, the Chinese Chairman always championed the cause of peasant revolution and, as China became more industrialized, made room for the proletariat to emerge as the vanguard class in China. Although Mao's decision to adopt a universalist brand of thought alienated his international followers from rural peasant-class societies, his advocacy for a worker-peasant alliance eliminated the gulf between the urban and agrarian masses. ${ }^{224}$ Historian Stuart Schram states that Mao did not tie his viewpoint "to the interests of a single class at a single time," but was "most passionately concerned with the fate of the Chinese nation, and moreover with its fate throughout all eternity." 225 Mao stated in a 1949 speech that the "people's democratic dictatorship is based on the alliance of the working class, the peasantry, and the urban petty bourgeoisie, and mainly on the alliance of the workers and the peasants because these two classes comprise 80 to 90 percent of China's population."226 Thus, a worker-peasant alliance exercised a dictatorship over the reactionary classes who resisted socialist transformation and construction. ${ }^{227}$

One of Tanzania's most pressing endeavors was to try to diminish the gulf between rural and urban peoples and the areas in which they lived. Historian John Saul argues that this was the Arusha Declaration's "most important aim" and the Mwogonzo guidelines in 1971 "provided ideological form for 
efforts to activate the necessary mass base of Tanzania's socialism." 228 Despite explicitly advocating that the reason for the ujamaa policy was the need to thwart the oppressive and reactionary classes, Nyerere and the Tanzanian Government never consolidated an alliance between the proletariat and peasantry. ${ }^{229}$ Instead, the Tanzanian President encouraged the maintenance of "reactionary and divisive classes" in ujamaa villages. ${ }^{230}$ Nyerere stated that Tanzanian peasants and workers "must not... persecute the progressive farmers... Instead we must seek their cooperation, and integrate them into the new socialist agriculture." 231 Under this stipulation, the wealthy peasants, known as kulaks, could maintain their stranglehold on rural production. ${ }^{232}$ Therefore, Nyerere failed to narrow the gap between the rich and poor, urban and rural classes in Tanzanian society.

\section{Conclusion}

Would Maoism be a catchall solution for all post-colonial quandaries? This paper has made clear the effectiveness of Mao's principles, but does not assume that such efficacy can be completely transposed to every country's particular conditions. However, Mao's precepts succeeded in the semi-feudal and semi-colonial case of Peru. The Shining Path localized Mao Zedong's principles by combining them with Peru's particular cultural forms. The Party also appropriated Mariátegui's notion of indigenismo to consolidate further support from Quechua peoples. Sendero gained strong peasant support in their millenarian struggle against the Peruvian government by extolling the importance of Andean culture and symbolism, by promoting the advancement of indigenous rights, and by tracing threads between the present struggle and past Peruvian attempts to end the unjust oppression of the Peruvian people. Contemporary scholars may fall into a temporal trap by merely foregrounding the fact that the Peruvian Maoists resorted to terrorism, cocaine trafficking, and extreme violence in their waning years of resistance, but the Shining Path successfully confronted the crooked Peruvian Government and made concerted efforts to improve the indigenous peoples' and peasants' standards of living.

In the Tanzanian case, however, Nyerere and the Tanzanian Government sought to forge a unique political ideology based on Nyerere's idealized version of traditional "African" notions of family and community.

Nyerere's socialism- embodied in his socio-economic program of ujamaa vjïinisought to shatter Tanzania's chain of dependency and to create a country that was productive, self-reliant, and egalitarian. While Mwalimu's ideas were remarkable, what actually happened on the ground was a total disaster. Thus, ujamaa exacerbated existing societal divisions, overworked the peasantry, reified the gulf between urban and rural, and effectively threw the country into a form of cyclical neo-colonial dependency. To conclude, the Peruvian case and the Tanzanian counter-example provide insight into the importance of global Maoism, the dif- 
ficulty in reconciling theory and practice, and the efficacy of "particularizing the universal" in settings disparate of its origin.

\section{NOTES}

${ }^{1}$ Karl Marx, Marx on China, 1853-1860: Articles from the New York Daily Tribune. (London: Lawrence \& Wishart, 1951), 7; Elizabeth J. Perry, "Reclaiming the Chinese Revolution," Journal of Asian Studies, 67, No.4 (November 2008): 1148.

2 Raymond F. Wylie, "Mao Zedong, Chen Po-ta, and the 'Sinification of Marxism," The China Quarterly 79, No.1 (September 1979): 447-480.

${ }^{3}$ Such studies include the following: Robert J. Alexander, International Maoism in the Developing World. (London, Praeger, 1999); William R. Heaton, "China and Southeast Asian Communist Movements: The Decline of Dual Track Diplomacy," Asian Survey 22, No. 8 (August 1982):779-800; Thomas A. Marks, Maoist People's War in Post-Vietnam Asia. (Chiang Mai, Thailand: White Lotus, 2007), xv; Alexander C. Cook, "Third World Maoism," in A Critical Introduction to Mao. Timothy Cheek, ed., (Cambridge: Cambridge University Press, 2010), 288312; Arif Dirlik, Paul Healy, and Nick Knight, eds., Critical Perspectives on Mao Zedong's Thought. (Amherst, New York: Prometheus Books, 1997). Alexander and Heaton explain Maoism's global emergence through the scope of international relations and as a nationalist response to the limitations of the Bolshevik model of organization. Marks, meanwhile, examines the global impact of Maoism through the perspective of strategy and operational art vis-à-vis Mao's military tactic of People's War. Cook and Dirlik et al. devote article length studies to Maoism outside China, but do not discuss Mao's concept model as a manner in which to explain the grafting of Maoism to extant ideological and cultural forms in the various Maoist movements.

${ }^{4}$ Mao Zedong, “On New Democracy," in Selected Works, Vol. II, 380-381, Knight, Mao Zedong, 44-47. For example, Mao used the traditional Chinese saying “相反相成” (xiangfan xiangcheng: things that oppose each other also complement each other), which shows an effort to blend China's particularities with Marx's universality.

5 Indigenismo: A Latin American social movement that pressed for an improved standard of living for the indigenous peoples of the Americas. Indigenismo also sought to grant a greater socio-political role for Indigenous peoples and the demanded a more steadfast recognition of indigenous rights and including compensation and reconciliation.

${ }^{6}$ Andean cultural and traditional norms: these include reciprocal justice, subsistence communal agriculture, the Inkarri myth, Pankainti, and the messianic notion of reuniting all the Andean peoples in a millenarian uprising against the state.

${ }^{7}$ Also referred to as ujamaa vijijini, Nyerere asserted that "we need to develop 
people, not things, and that people can only develop themselves." See Julius Nyerere, Man and Development. (Dar es Salaam: Oxford University Press, 1974), 36-37.

8 Abdul Rahman Babu, African Socialism or Socialist Africa? (London: Zed Press, 1981), 4-8, 53, 58, 154, 146-147, 163-165.

9 Timothy Cheek, "Mao, Revolution, and Memory," in A Critical Introduction to Mao. Timothy Cheek ed., (Cambridge: Cambridge University Press, 2010), 13.

10 O.W. Wolters, History, Culture, and Region in Southeast Asia. (Ithaca, New York: Cornell Southeast Asia Program Publications, 1999), 56-57.

11 Wolters, History, 56.

12 Ibid., 55.

13 Arnd Schneider, “On 'Appropriation': A Critical Reappraisal of the Concept and its Application in Global Art Practices," Social Antbropology 11 (2003): 224, as cited in Laura L. Adams, "Globalization, Universalism, and Cultural Form," Comparative Studies in Society and History 50, No. 3 (2008): 616.

14 Schneider, "On 'Appropriation"” 224, as cited in Adams, "Globalization," 616.

15 Arjun Appadurai, "Disjuncture and Difference in the Global Cultural

Economy,” Theory, Culture \& Society 7, No. 1 (November 2007): 295.

16 Adams, "Globalization," 616.

${ }^{17}$ Michel de Certeau, The Practice of Everyday Life. (Berkeley, California: University of California Press, 1984), as cited in Jeremy Prestholdt, "Similitude and Empire: On Comorian Strategies of Englishness," Journal of World History 18, No. 2 (2007): 114-115.

18 Wolters, History, 55. Theravada Buddhism: Literally "the Teaching of the Elders" or "the Ancient Teaching" is the oldest surviving Buddhist school. Founded in India, Theravada Buddhism is relatively conservative and generally considered closest to early Buddhism.

19 Raymond F. Wylie, The Emergence of Maoism: Mao Tse-tung, Chen Po-ta, and the Search for Chinese Theory. (Stanford, Stanford University Press, 1980), 77.

20 Tang Tsou, The Cultural Revolution and Post-Mao Reforms: A Historical Perspective. (Chicago: University of Chicago Press, 1986), 114.

21 Wylie, "Mao Zedong, Chen Po-ta," 447.

22 Ibid., 447.

23 Mao Zedong quoted in Wylie, The Emergence, 88.

24 Ibid., 88. Marxist features: the materialist concept of history (conflict between social classes), critique of capitalism's exploitation of the urban proletariat, and the theory of a proletarian revolution. Mao believed strongly that there was only concrete Marxism, which he defined as Marxism "that has taken on a national form... [and has been] applied to the concrete struggle in the concrete conditions prevailing in China, and not abstractly used." See Stuart Schram, The 
Political Thought of Mao Zedong. (New York: Praeger, 1969), 172.

25 Hans van de Ven, "War, Cosmopolitanism, and Authority," in A Critical Introduction to Mao. Timothy Cheek ed., (Cambridge: Cambridge University Press, 2010), 87.

26 Stuart Schram, The Political Thought of Mao Zedong (New York: Praeger, 1969), 72-73, 79-80. See also Maurice Meisner, Li Ta-Chao and the Origins of Chinese Marxism. (New York: Atheneum, 1970), xiv; Jack Gray, Mao Tse-tung (London: Lutterworth Press, 1973), 41; Jack Gray, "Mao in Perspective," China Quarterly 187 (September 2006): 669-673; Mark Selden, The Yenan Way. (Cambridge, Massachusetts: Harvard University Press, 1971), 119-120, 191; Frederic E. Wakeman, History and Will: Philosophical Perspectives on Mao Zedong Thought. (Berkeley, California: University of California Press, 1973), 195-205, 291. 27 Schram, The Political, 112-116.

28 Mao Zedong, "On New Democracy," in Selected Works Vol. II, 342-347, 351352. Mao clearly states that China's revolution is indeed "part of the world revolution," and that the Chinese communists put forward this idea as early as the mid-1920s. Mao asserts that the communists unanimously accepted that China's revolution was proletarian-internationalist and not bourgeois-nationalist.

${ }^{29}$ Healy in Dirlik et al., 145.

30 Nick Knight, "The Laws of Dialectical Materialism in Mao Zedong's Thought: the Question of 'Orthodoxy'.” Dirlik et al., 105-106.

31 Karl Marx, "Communism, Revolution, and a Free Poland," [www.marxists.org/archive/marx/works/1848/02/22a.htm] (Accessed 29 November 2012); Freidrich Engels, "The Prague Uprising," [http://www.marxists.org/archive/marx/works/1848/06/18.htm] (Accessed 29 November 2012). 32 Nick Knight, Marxist Philosophy in China: From Qu Qiubai to Mao Zedong, $1923-$ 1945. (Dordrecht, the Netherlands: Springer, 2005), xi. Here, Knight accepts the philosophical credentials of China's revolutionary philosophers such as Qu Qiubai, Mao Zedong, Li Da, Ai Siqi, which distances his work from much of the Western literature on Marxist philosophy and ideology in China.

33 Raymond F. Wylie, The Emergence of Maoism: Mao Tse-tung, Chen Po-ta, and the Search for Chinese Theory, 1935-1945. (Stanford: Stanford University Press, 1980), 7, 80, 89-91; Wylie, "Mao Tse-tung," 462-463. Chen's interpretation of Marxism, he argues, was threefold: first, Marxism had "antecedents in traditional Chinese culture"; second, Marxism "can be adapted to the specific environment of China; and third, Marxism "can be enriched and developed through application in China."

34 Wylie, The Emergence, 52; Wylie, "Mao Tse-tung," 462.

35 Wylie, The Emergence, 4, 6-7, citing Michel C. Oksenberg, "Policy Making Under Mao, 1949-1968: An Overview," in China: Management of a Revolutionary Society. John M. H. Lindbeck, ed. (London: Allen and Unwin, 1971), 92; Michel 
C. Oksenberg, "The Political Leader," in Mao Tse-tung in the Scales of History. Dick Wilson, ed., (Cambridge: Cambridge University Press, 1997), 94; Wylie, "Mao Tse-tung," 447-480. Wylie draws from Chen Boda's own writings and papers by leading CCP officials such as Mao and Liu Shaoqi to support his point.

36 Robert C. North, Moscow and Chinese Communists. (Stanford: Stanford University Press, 1963), 193; Karl A. Wittfogel, "The Influence of Leninism-Stalinism on China," Annals of the American Academy of Political and Social Science 277, Report on China (September 1951): 22-34; Wylie, "Mao Tse-tung," 463. Wylie notes that in lieu of the rising opposition of the pro-Soviet Returned Students led by Wang Ming, Chen and his fellow Mao supporters "made certain that there would be no serious opposition to Mao's claim to political and theoretical supremacy within the CCP" through years of political work and a strong, unified stance in opposition to other ideologies. Mao and Chen, thus, employed Sinification in "decidedly political ways... [in] the swelling Maoist campaign against Wang Ming and the Returned Students." See Wylie, The Emergence, 282-283.

37 Meisner, Mao Zedong, 52-54.

38 Ibid., 52-54, 82, 100.

${ }^{39}$ Lee Feigon, Mao: A Reinterpretation (Chicago: Ivan R. Dee, 2002), 11.

40 Feigon, 182-183. Feigon states that Mao Zedong's break with the Stalinists was "fundamental" and this important intraparty divorce allowed him to develop "a new ethos devoted to greater sexual, educational, and economic equality." 41 Nick Knight, Rethinking Mao: Explorations in Mao Zedong Thought. (Lanham, Maryland: Rowman \& Littlefield, 2007), 197; Arif Dirlik, Marxism in the Chinese Revolution. (Lanham, Maryland: Rowman \& Littlefield, 2005), 79.

42 Nick Knight, "The Form of Mao Zedong's 'Sinification of Marxism', The Australian Journal of Chinese Affairs, No. 9 (January 1983): 18.

43 Dirlik, Marxism,79; Knight, "The Form," 20; Knight, "Mao Zedong and the 'Sinification of Marxism'," 85. See also Mao Zedong, "On New Democracy," in Selected Works, Vol. II, 342-352.

44 Mao Zedong, "On New Democracy," in Selected Works, Vol. II, 380-381;

Knight, "Mao Zedong and the 'Sinification of Marxism'," 86. Knight states that Mao "believed that the abstract universal laws of Marxism performed an important function in directing attention to those aspects of society requiring analysis and study," but these universals "did not by themselves represent Marxism in its entirety." Therefore, Marxism required particularization to become a "complete ideology."

45 Nick Knight, Re-thinking Mao: Explorations in Mao Zedong's Thought. (Lanham, Maryland: Rowman \& Littlefield, 2007), 199, 201. Knight states that according to Mao, although laws of the universal status existed, it was also possible to derive laws that did not have universal status and that were applicable only to particular instances within a general category. For Mao's speech on universal and particular 
laws, see Mao Zedong, Selected Works, Volume 5. (Beijing: Foreign Language Press, 1977), 284-307.

46 Knight, Rethinking, 213.

47 Van de Ven, "War," in Cheek ed., 87.

48 Based on the Incan goddess Panchamama. She is a revered earth goddess in Incan myths and culture.

49 Orin Starn, Carlos Ivan Degregori, and Robin Kirk, eds., The Peru Reader: History, Culture, Politics. (Durham, North Carolina: Duke University Press, 1995), 305, and Alexander C. Cook, "Third World Maoism," in Cheek, ed., 87.

50 Matt Rothwell, "Transpacific Revolutionaries: The Creation of Latin American Maoism," in New World Coming, Karen Dubinsky et al. eds., (Toronto: Between the Lines Press, 2008), 107.

51 Rothwell, "Transpacific," in Dubinsky et al., eds., 107. People's War had three protracted war stages: strategic defensive, strategic stalemate and the strategic offensive. People's War was not a strategy of aggression but instead was a strategy of aggressive defense. As Mao stated, "the enemy advances, we retreat; the enemy camps, we harass; the enemy tires, we attack; the enemy retreats, we pursue." Mao Zedong, "A Single Spark Can Start a Prairie fire," Selected Works, Volume 1, 124; Mao Zedong, "On Protracted War," Selected Works, Vol. II, 115$117,156$.

52 Mark Selden, The Yenan Way in Revolutionary China. (Cambridge, Massachusetts: Harvard University Press, 1971), vii.

53 To localize Maoism, the CPP-SP appropriated Peru's socialist hero, Jose Carlos Mariátegui and his theory of “indigenismo." Like Mao, Mariátegui argued that a socialist revolution should evolve organically in a different context and be based on unique local conditions and practices rather than the result of applying a Eurocentric formula to a non-European context.

54 Starn, Degregori, and Kirk, The Peru Reader, 305.

55 Starn, "Maoism in the Andes," 406-407.

56 Starn, Degregori, and Kirk, The Peru Reader, 306-307.

57 Carlos Ivan Degregori, "Return to the Past," in Shining Path of Peru, David Scott Palmer ed., (New York: St. Martin's Press, 1992), 33-44.

58 Degregori, "Return to the Past," in Palmer ed., 33-44.

${ }^{59}$ Cook, "Third World Maoism," in Cheek, ed., 307.

60 Billie Jean Isbell, "The Emerging Patterns of Peasant Responses to Sendero Luminoso," unpublished paper, 1988, as cited in Daniel Masterson, "In the Shining Path of Mariátegui, Mao Zedong, or Presidente Gonzalo? Peru’s Sendero Luminoso in Historical Perspective," in Revolution and Revolutionaries: Guerrilla Movements in Latin America, Daniel Castro ed. (Wilmington, Delaware: Scholarly Resources Inc., 1999), 181. 
61 Carlos Ivan Degregori, El Surgimiento de Sendero Luminoso. (Lima, Peru: Instituto de Estudios Peruanos, 1990), 270; Masterson, "In the Shining Path," 181.

62 Sendero Luminoso: means "Shining Path" in Spanish. The nickname is homage to a maxim of Jose Carlos Mariátegui, founder of the original Peruvian Communist Party in the 1920s. The infamous phrase/slogan reads: El MarxismoLeninismo abrira el sendero luminoso hacia la revolución (Marxism-Leninism will open the shining path to revolution).

63 Emphasis added. Masterson argues that the faith in the ability of Peru's indigenous population to rebuild the nation within the traditional communalistic framework has never been expressed by the self-styled CPP-SP.

64 Masterson, "In the Shining Path," 184.

65 Orin Starn, "Peasants at War: Rural Defense Committees in Peru's Highlands," unpublished paper, 1991, as cited in Masterson, "In the Shining Path," 182.

66 Ibid., 181-182.

67 Ibid.,181-182.

68 The TRC, which was borne out of the aftermath of a two-decade long struggle between the Shining Path and the Fujimori government, brands Sendero as a terrorist group and has thus far failed to bring any truth or reconciliation to a struggling Peru. Racial discrimination and social divides remain dominant presences in the post-Fujimori years.

${ }^{69}$ Edward L. Cleary, "New Voice in Religion and Politics in Bolivia and Peru," in Resurgent Voices in Latin America: Indigenous Peoples, Political Mobilization, and Religious Change. Edward L. Cleary and Timothy J. Steigenga eds., (New Brunswick, New Jersey: Rutgers University Press, 2004), 52. Campesin (peasant) replaced indio (Indian) while Indigena (indigenous) was reserved for the people from the easternmost forest region.

70 Cleary, "New Voice," 43.

71 Robert J. Alexander, International Maoism in the Developing World. (Westport, Connecticut: Praeger, 1999), 153-154.

72 Mao Zedong, “On New Democracy,” Selected Works, Vol. II, 341.

73 Jose Carlos Mariátegui, Seven Interpretive Essays on Peruvian Reality. (Austin, Texas, 1971), 163-164; Masterson, "In the Shining Path," 172-174. Mariátegui wrote that communism "has continued to be the Indian's only defense." Individualism cannot flourish "or even exist effectively outside a system of free competition. And the Indian has never felt less free than when he has felt alone."

74 Masterson, "In the Shining Path," 174.

75 Ibid., 174. Mao Zedong was in the process of building his peasant-driven van- 
guard in the Chingkangshan Mountains at around the same time. Mao Zedong, "Report on an Investigation of the Peasant Movement in Hunan," (March 1927) [http://www.marxists.org/reference/archive/mao/selected-works/volume1/mswv1_2.htm] (Accessed 27 January 2011).

76 Masterson, "In the Shining Path," 174.

77 Ibid., 174.

78 Mariátegui emphasized the dignity of labor as a key element of the human condition, but unlike Marx, he did not view labor in exclusively economic terms. As Masterson notes, instead of "wedding himself to the concept of 'surplus value,' Mariátegui viewed Andean labor in its variety of reciprocal forms as a means of maintaining values and community solidarity." Masterson, "In the Shining Path," 174.

79 Ibid., 174. Emphasis added.

80 Mariátegui, Seven Interpretive Essays on Peruvian Reality. 77-124, as cited in Masterson, "In the Shining Path," 174.

81 Quechua: the name of a people of the central Andes of South America and the descendants of the Incas.

82 Mariátegui, Seven Interpretive Essays on Perwian Reality. 61. He stated that that up to now "neither the science of sociology nor the empiricism of the great industrialists" have been able to solve these two great economic and social principles satisfactorily.

83 Alexander, International Maoism in the Developing World. 154. Eudosi Ravines reorganized the Socialist Party as the Communist Party of Peru, which became a full member of the Comintern.

${ }^{84}$ Lewis Taylor, Shining Path: Guerrilla War in Peru's Northern Highlands, 1980-1997. (Liverpool, England: Liverpool University Press, 2006), 10-11, as cited in Cook, “Third World Maoism," in Cheek, ed., 305.

85 "Interview with Chairman Gonzalo," in El Diario, trans. By the Peru People's Movement (Red Banner Publishing House, 1988); reproduced by Red Sun; [www.redsun.org/pcp_doc/pcp_0788.htm] (Accessed 7 January 2011).

86 Cook, "Third World Maoism," in Cheek, ed., 305.

87 Gustavo Gorriti, The Shining Path: A History of the Millenarian War in Peru. (Chapel Hill, North Carolina, UNC Press, 1999), 46.

88 Olin Starn, "Maoism in the Andes: The Communist Party of Peru-Shining Path and the Refusal of History," Journal of Latin American Studies, 27, No. 2 (May, 1995): 404.

89 Starn, "Maoism in the Andes," 404.

90 Starn, Degregori, and Kirk, The Peru Reader, 305; Cook, "Third World Maoism," in Cheek, ed., 304.

91 Central Committee of the Communist Party of Peru, "Interview with 
Chairman Gonzalo," 11, in Starn, "Maoism in the Andes," 404; Cook, "Third World Maoism," in Cheek, ed., 304. The Shining Path emerged from factional politics within the Peruvian Communist Movement. Peruvian Maoists first split from the main Communist Party in 1964, rejecting Soviet and Cuban influences. According to Starn, Guzman "belonged to the Communist Party of Peru-Red Flag until 1970, when, apparently dissatisfied with the unwillingness of the leadership of Red Flag to take up arms against the Peruvian government, he led a splinter movement to found the Shining Path."

92 Abimael Guzman, "We Are the Initiators," 19 April 1980.

[http://www.duke.edu/ ems19/teaching/shining_path.html] (Accessed 16 January 2011), "Interview with Chairman Gonzalo," in El Diario, trans. by the Peru People's Movement, Red Banner Publishing House, 1988; reproduced by Red Sun; [www.redsun.org/pcp_doc/pcp_0788.htm] (Accessed 29 January 2011), Abimael Guzman, "We Are the Initiators," 19 April 1980.

[http://www.duke.edu/ ems19/teaching/shining_path.html] (Accessed 16 January 2011), and Alexander, 153.

93 Cynthia McClintock, “Why Peasants Rebel: The Case of Peru's Sendero Luminoso," World Politics, 37, No. 1 (October 1984): 83-85.

94 Gabriela Tarazona-Sevillano, Sendero Luminoso and the Threat of Narcoterrorism. (New York: Praeger, 1990), 197, as cited in Michael P. Arena and Bruce A. Arrigo, The Terrorist Identity: Explaining the Terrorist Threat. (New York: NYU Press, 2006), 166.

95 Tarazona-Sevillano, Sendero Luminoso..., 197.

96 Arena and Arrigo, The Terrorist Identity, 164. Emphasis added. Mao argued that revolutions in colonies, or semi-colonial semi-feudal states, had to take place in two stages: first, a "democratic revolution," carried out by an alliance of different classes, and afterwards a "socialist revolution." Even though he was adamant that the bourgeoisie were "unreliable allies who would turn tail at the first sign of trouble, the New Democracy phase of revolution was "necessary and cannot be dispensed with." Mao Zedong's emphasis on the power of the people as revolutionary forces further enhanced Mao's theory of New Democracy. China's new politics, economy and culture were "the politics, economy and culture of New Democracy," and called for the people to develop a revolutionary spirit that the Chairman himself regarded as the driving force behind New Democracy. It was the duty of people throughout the world to "put an end to the aggression and oppression perpetrated by imperialism." See Mao Zedong, "On New Democracy," Selected Works, Vol. II, 341-343.

97 Cook, "Third World Maoism," in Cheek, ed., 304. According to Cook, "the locals called him the 'Red Sun' in their indigenous language, whereas his critics called him 'Shampoo' for his brainwashing abilities."

98 The peasantry is an unclear social category because its meaning has been 
defined and redefined to the point of nearly rendering the group as useless. Allen Isaacman argues that many have grappled "with the idea of the development of peasantries, analyzing such broader processes as the uneven capitalist penetration of the countryside, the growth of commodity production, the restructuring of gender and household relations, and the development of oscillating peasant workers." He cautions historians to avoid categorization and praises Africanists for paying greater attention to the voices of a varying degree of peasants. These voices, he declares, "need to be listened to critically and carefully, precisely because there is no authentic voice or transcending unity that structured the diverse experiences of African peasantries." By placing the focus on different peasantries and how they negotiate their positions in relation to the labor process, he asserts, we emphasize the fact that peasants subsist as "part of a larger social order, in which ruling class agendas, state politics, and international markets impinge on their daily lives and subsume a portion of their labor." Allen F. Isaacman, "Peasants and Rural Social Protest in Africa," in Confronting Historical Paradigms: Peasants, Labor, and the Capitalist World System in Africa and Latin America. Fred Cooper, Allen F. Isaacman, Florencia E. Mallon, William Roseberry and Steven J. Stern eds., (Madison, Wisconsin: University of Wisconsin Press, 1993), 205-209.

99 La Comisión de la Verdad y Reconciliación, Final Report. Lima, Peru: Comision de la Verdad y Reconciliacion, 2001.

[http://www.cverdad.org.pe/ingles/ifinal/conclusiones.php] (Accessed 11 January 2011), and Ronald H. Berg, "Sendero Luminoso and the Peasantry of Andahuaylas," Journal of Interamreican Studies and World Affairs, 28, No. 4 (Winter 1986-1987): 192.

100 Cynthia McClintock, "Why Peasants Rebel: The Case of Peru's Sendero Luminoso," World Politics 37, No. 1 (October 1984): 64.

101 Arena and Arrigo, The Terrorist Identity, 164.

102 Ronald H. Berg, "Sendero Luminoso and the Peasantry of Andahuaylas," Journal of Interamerican Studies and World Affairs 28, No. 4 (Winter 1986-1987): 192; Cleary, "New Voice in Religion and Politics in Bolivia and Peru," 52; Xavier Albo, Pueblos Indios en la Politica. (La Paz, Bolivia: Plural Editores, 2002), 181-182. Cleary and Xavier Albo argue that political parties, from the right and the left, wanted to put an end to the idea of ethnic identities acting in opposition to the state. As Albo mentions, the Peruvian state wanted to be universal and monopolistic in its control. Victor Hugo Cardenas argues that a close reading of indigenous history shows that indigenous communities have a quality of being ministates. Thus, the indigenous peoples were being "ethnically-cleansed."

103 Mestizo: The intermarriage of Spanish whites and indigenous peoples. The creole offspring dominated the hacienda economy for centuries and marginalized the Indian to near extinction. 
104 Berg, "Sendero Luminoso and the Peasantry of Andahuaylas," 188. As Berg notes, there was an ethnic dimension as well. As he states, the Spanish word "campesino contains both class and ethnic connotations. When asked to explain the term, people described a person who is "poor, like us" i.e. like us of the villages. Yet there is a clear ethnic dimension as well, since the "rich" live in the towns, do not speak Quechua, practice standard Catholicism, and dominate the peasants. When people debated the morality of killing a person, the discussion centered upon whether or not, or to what extent, he or she was a campesino/a." 105 Berg, "Sendero Luminoso and the Peasantry of Andahuaylas," 186. That said, violence against peasants did occur. See Cleary, "New Voice in Religion and Politics in Bolivia and Peru," 59-60.

106 Berg, "Sendero Luminoso and the Peasantry of Andahuaylas," 187. Namely, unfair exchange meant buying grain at a low price and selling it at a high price. According to Berg, the victims "had received bank loans, which gave them plenty of cash with which to buy materials and hire laborers, while others had nothing."

107 Berg, "Sendero Luminoso and the Peasantry of Andahuaylas," 192.

108 Arena and Arrigo, The Terrorist Identity, 163.

109 Stefano Varese, "The Ethnopolitics of Indian Resistance in Latin America," Latin American Perspectives 23, No. 2, Ethnicity and Class in Latin America (Spring 1996): 65; Cleary, "New Voice in Religion and Politics in Bolivia and Peru," 43. Cleary states that the resurgence of Indian populations in Latin America "is strongly evident in Peru" and the reasons for the resurgence "concern the struggles to revitalize what were considered dying traditional cultures."

110 Varese, "The Ethnopolitics of Indian Resistance in Latin America," 65, 70; Arena and Arrigo, The Terrorist Identity..., 163, citing R.B. Davis, "Sendero Luminoso and Peru's Struggle for Survival," Military Review 70, No. 1 (1990): 75 88. Tupac Amaru I was also referred to by his divine name, Inkarri. According to Varese, this can mean Inka Rey and or the Inka-ri, word/speech/spirit, founding principles of all things in the universe.

111 Arena and Arrigo, The Terrorist Identity, 163.

112 Carlos Ivan Degregori, "Return to the Past," in The Shining Path of Peru, David Palmer ed., (New York: St. Martin's Press, 1994), 62.

113 Arena and Arrigo, The Terrorist Identity, 163.

114 John Daly, "The USSR and Sendero Luminoso: Marxist Rhetoric versus Maoist Reality," Low Intensity Conflict and Law Enforcement 6, No. 1 (1997): 27-52; D.W. Fitzsimmons, "Sendero Luminoso: Case Study in Insurgency," Parameters 23, No. 2 (1993): 64-73; Simon Strong, Shining Path: The World's Deadliest Revolutionary Force. (London: Harper Collins, 1992); G. Vasquez, "Peruvian Radicalism and the Sendero Luminoso," Journal of Political and Military Sociology 21, No. 1 (1993): 197-217. 
115 Varese, "The Ethnopolitics of Indian Resistance in Latin America," 65; Arena and Arrigo, The Terrorist Identity, 163.

116 Varese, "The Ethnopolitics of Indian Resistance in Latin America," 65, 70. 117 Ibid., 70.

118 Arena and Arrigo, The Terrorist Identity..., 163-164.

119 Ibid., 163-164.

120 Second stage of Maoist revolution: agitation and propaganda, reached on May 17, 1980.

121 Third stage of Maoist revolution: generalized violence and guerrilla warfare, reached in 1982.

122 Fourth stage of Maoist revolution: the conquest and expansion of the support base, reached in late 1988 .

123 Arena and Arrigo, The Terrorist Identity, 158-160.

124 Cook, "Third World Maoism," in Cheek, ed., 307.

125 Starn, Degregori, and Kirk, the Peru Reader, 305.

126 La Comisión de la Verdad y Reconciliación, Final Report. Lima, Peru:

Comision de la Verdad y Reconciliacion, 2001.

[http://www.cverdad.org.pe/ingles/ifinal/conclusiones.php] (Accessed 11 January 2011).

127 Cook, Third World Maoism," in Cheek, ed., 304-305. Guzman described himself as the "greatest living Marxist-Leninist." As the intellectual successor to Marx, Lenin, and Mao, his "Gonzalo Thought" became the "Fourth Sword of Marxism.' According to Starn, a Mao-like personality cult developed around Guzman very early in the movement, and the CPP-SP would later make use of such Cultural Revolution agitprop staples as incendiary wall posters and dunce caps for enemies, even to the point of reciting Mao songs in Mandarin. Orin Starn, "Maoism in the Andes: The Communist Party of Peru-Shining Path and the Refusal of History," in Critical Perspectives on Mao Zedong Thought. Dirlik et al., eds., 276.

128 Senate Congressional Record, "Peru and the Capture of Abimael Guzman," (2 October 1992), S16332. [http://www.fas.org/irp/congress/1992_cr/s921002terror.htm]. (Accessed 11 January 2011).

129 Gustavo Goritti, The Shining Path: A History of the Millenarian War in Peru. (Chapel Hill, North Carolina: University of North Carolina Press, 1999), 185. 130 Michael L. Smith, "Taking High Ground: Shining Path and the Andes," in Shining Path of Peru. David Palmer ed., (New York: St. Martin's Press, 1992), 17. 131 George T. Yu, China and Tanzania: A Study in Cooperative Interaction. (Berkeley, California: University of California Center for Chinese Studies, 1970), 11-13, 3234, 75; Margaret Hall and Tom Young. Confronting Leviathan: Mozambique since Independence. (Athens, Ohio: Ohio University Press, 1997), 13. 
132 Jamie Monson, Freedom Railway: How a Chinese Development Project Changed the Lives and Livelihoods in Tanzania. (Bloomington, Indiana: Indiana University Press, 2009), 28; Goran Hyden, Beyond Ujamaa in Tanzania: Underdevelopment and an Uncaptured Peasantry. (Berkeley, California: University of California Press, 1980), 100. Julius Nyerere was greatly influenced by the rural development he witnessed during his many visits to China in 1965, 1968 and 1974. According to Monson and Hyden, Nyerere commented often in public on the commitment to hard work and diligence that he had seen in rural Chinese villages.

133 Tanzania: Tanganyika and Zanzibar merged to form Tanzania on 26 April 1964.

134 TANZARA: Railway built to link Zambia to Dar es Salaam. China spent $\$ 500$ million US to finance the project and sent hundreds of laborers, technical advisers, and Red cadres to help assist with the development.

135 Monson, Freedom Railway, 26-28.

136 May Joseph, Nomadic Identities: The Performance of Citizenship. (Minneapolis, Minnesota: University of Minnesota Press, 1999), 40; Martin Bailey, "Tanzania and China," African Affairs 74, No. 294 (January 1975): 42. Ailey asserts that ujamaa, "which attempts to communalize the way of life and production of the peasantry, have been partly inspired by the success of the Chinese communes." However, he emphasizes that the major influence on Nyerere "was his understanding of traditional African society rather than the Chinese experience." 137 Hyden, Beyond, 108-121. Emphasis added.

138 Ibid., 117.

139 Works under study include the following: Cranford Pratt, The Critical Phase in Tanzania, 1945-1968: Nyerere and the Emergence of a Socialist Strategy. (Cambridge: Cambridge University Press, 1976); Issa G. Shivji, Class Struggles in Tanzania. (New York: Monthly Review Press, 1976); P. L. Raikes, "Ujamaa and Rural Socialism," Review of African Political Economy, No. 3 (May-October, 1975): 33-52; Jean Francois Bayart, The State in Africa: The Politics of the Belly. (Cambridge: Polity Press, 2006); and Michael Schatzberg, Political Legitimacy in Middle Africa: Father, Family, Food. (Bloomington, Indiana: Indiana University Press, 2001).

140 “To Serve the World's People with Sincerity," Renmin Ribao, 15 March 1968, as cited in Monson, Freedom Railway, 28.

141 Monson, Freedom Railway, 26-28, citing Jaycox in a telephone interview, (26 October 1999). Monson also states that in a personal communication, his other colleague Lorne Larson stated that he remembers ubiquitous Mao buttons in Tanzania at the same time.

142 Hall and Young, Confronting Leviathan, 13; Barry Munslow, Mozambique: the Revolution and its Origins. (New York: Longman, 1983), 90. Tanzanian-trained guerrillas were expected to carry out sabotage operations, destroy bridges, interrupt commerce and lay ambushes against colonial outposts. 
143 Bonny Ibhawoh and J.I. Dibua, "Deconstructing Ujamaa: The Legacy of Julius Nyerere in the Quest for Social and Economic Development in Africa," African Journal of Political Science, 8, No. 1 (2003): 62; Goran Hyden, "Mao and Mwalimu: The Soldier and the Teacher as Revolutionary," Transition, No. 34 (December 1967 - January 1968): 25. Hyden states that the Tanzanian revolution was "carried out in the Christian and Islamic tradition rather than in the name of Marx, Lenin, or Mao."

144 Hyden, "Mao and Mwalimu," 25. Nyerere stated in 1967 that Tanzania's acceptance of the Arusha Declaration "was like a young Christian's confirmation; it is a declaration of intent to live a certain kind of life and to act in a certain kind of manner for desired ends." See Nyerere, Freedom and Socialism, 385.

145 Ibhawoh and Dibua, "Deconstructing Ujamaa," 62.

146 Hyden, "Mao and Mwalimu," 25.

147 Kambona argued that ujamaa must first be tested in small communities before spreading the program across the nation.

148 Joseph, Nomadic Identities, 40. The Arusha Declaration's philosophy of governance and economics of self-reliance aimed to "redefine the participation of indigenous peoples as actors within their own state. It produced a system of state control whose rhetoric announced a radical realignment of private interests as state interests, through policies that articulated the redistributions of wealth, land, and international dependency relationships. The declaration was an elaborate philosophical argument to disengage from the systems of capital that would create neocolonial economies subordinate to and dependent on former imperial powers."

149 Julius Nyerere quoted in Gavin Kitching, Development and Underdevelopment in Historical Perspective. (London: Methuen \& Co. Ltd., 1982), 64. According to Nyerere, the foundation and objective of African socialism is "the extended family... Ujamaa, then, is opposed to capitalism, which seeks to build a happy society on the basis of exploitation of man by man; and it is equally opposed to doctrinaire socialism which seeks to build its happy society on a philosophy of inevitable conflict between man and man. We, in Africa, have no more need of being taught democracy. Both are rooted in our own past. Modern African socialism can draw from its traditional heritage the recognition of society as an extension of the basic family unit."

150 Julius Nyerere, "Socialism and Rural Development," (Dar es Salaam, Tanzania: Oxford University Press, 1968), 337-366; Cranford Pratt, The Critical Phase in Tanzania, 1945-1968: Nyerere and the Emergence of a Socialist Strategy. (Cambridge: Cambrdige University Press, 1976), 3-5; Dean McHenry, “The Ujamaa in Tanzania: A Comparison with Chinese, Soviet, and Mexican Experiences in Collectivization," Comparative Studies in Society and History 18, No. 3, (9 July 1976): 348. 
151 Julius Nyerere, Freedom and Socialism: a Selection from Writings and Speeches, $1965-$ 1967. (Dar es Salaam, Tanzania: Oxford University Press, 1968), 405-406; Julius Nyerere, Ujamaa: Essays on Socialism. (Dar es Salaam: Oxford University Press, 1968), 1-12, 106-108.

152 Nyerere, Freedom and Socialism, 405; Nyerere, Ujamaa: Essays on Socialism, 3-6, 106-109.

153 Nyerere, Freedom and Socialism, 405.

154 This is perhaps why ujamaa failed to come together as a uniquely "African" cultural project.

155 Elisabeth J. Croll, "Women in Rural Production and Reproduction in the Soviet Union, China, Cuba and Tanzania: Case Studies," Signs 7, No. 2 (Winter 1981): 393.

156 Croll, "Women in Rural Production...," 393.

157 Nyerere, Freedom and Socialism, 405; Nyerere, Ujamaa: Essays on Socialism, 110111.

158 Nyerere, Freedom and Socialism, 405.

159 Roger Lewin and Griffiths Cunningham, "The Prospects for Ujamaa

Villages," in Self-Reliant Tanzania, Svendsen and Teisen, eds., (Dar es Salaam, Tanzania: Tanzania Publishing House, 1969), 275, cited in McHenry, "The Ujamaa in Tanzania," 357; Croll, "Women in Rural Production," 393.

160 Ibhawoh and Dibua, 68, Croll, 393. Nyerere argued that ujamaa as production units allowed for the collectivization of the means of production and a change in the relations of production.

161 Pratt, Critical Phase, 6-7. Emphasis added. Pratt states that Nyerere's “ideology, his aspirations and indeed his personal characteristics have been extremely important determinants of government policies"

162 Pratt, "Julius Nyerere," 138-145.

163 Pratt, Critical Phase, 4-5, 236; Pratt, “Julius Nyerere,” 144-149.

164 Pratt, Critical Phase, 5.

165 Pratt, Critical Phase, 245-248; Pratt, "Julius Nyerere," 144-145. According to Pratt, Nyerere valued an "equality" that was "not an equality of initial opportunities for autonomous individuals. Rather it was the equality enjoyed in closely integrated and caring societies such as Nyerere assumed most Tanzanian tribal societies had been and indeed still were."

166 Pratt, "Julius Nyerere," 146. Emphasis added.

167 Pratt, The Critical Phase, 154-156; Cranford Pratt, "Democracy and Socialism in Tanzania: A Reply to John Saul," Canadian Journal of African Studies / Revue Canadienne des Études Africaines 12, No. 3 (1978): 407-428; Cranford Pratt, "Julius Nyerere: Reflections on the Legacy of his Socialism," Canadian Journal of African Studies / Revue Canadienne des Études Africaines 33, No. 1 (1999): 137-138, 140-142, 
150; Nyerere, Man and Development, 35. Nyerere refused to espouse Marxism as his political ideology and insisted on the creation of an African socialism. He states "in very few cases was any ideology involved; we thought and talked in terms of greatly increased output, and of things being provided for the settlers."

168 Only Shivji and Raikes are examined due to the constraints of this paper. Another noted Marxist, John Saul, argues that Africa "can only liberate itself continentally, not nationally. He states that it is well known that Tanzania has provided facilities and much freedom of maneuver for Mozambican revolutionaries as they move south... Tanzania has increasingly been the guarantor of the emergence of the most progressive tendencies among the Mozambican revolutionaries; even in this indirect manner, therefore, it has also contributed to the militancy of the struggle there." See John Saul, "Frelimo and the Mozambique revolution," in Essays on the Political Economy of Africa, Giovanni and John Saul eds., (London: Monthly Review Press, 1973), 262-273.

169 Issa Shivji, “Tanzania: The Class Struggle Continues," Development Studies, (University of Dar es Salaam, 1973), 46, 99, as cited in McHenry, "The Ujamaa in Tanzania," 359. Emphasis added; Julius Nyerere, "Socialism and Rural Development," (Dar es Salaam, Tanzania: Oxford University Press, 1968), 342344. Nyerere asserted that the ujamaa village policy was to prevent the development of an elite land owning class.

170 Issa Shivji, "Peasants and Class Alliances," Review of African Political Economy, No. 3 (May-October 1975): 10-12.

171 Shivji, "Peasants," 10.

172 Shivji, "Peasants," 10-12. Shivji states that the "externally-oriented, commercial economy acts like a 'sucking pump' for all capital, in whatever sector it originate[d]. In Tanzania, petty trade, transport, shops and real estate, are the economic activities that the rich peasants immediately enter into as soon as they have made some cash in the agricultural activity."

173 Shivji, "Peasants," 10, 14. Shivji postulates that the notion of a worker peasant alliance has been terribly misunderstood by radical academics. This is so since there has been "no example in Africa where the peasants have played a leading revolutionary role while workers have sided with the dominating classes." 174 Shivji, "Peasants," 10.

175 Issa Shivji, Class Struggles in Tanzania. (London: Monthly Review Press, 1976), 21.

176 P.L. Raikes, "Ujamaa and Rural Socialism," Review of African Political Economy, No. 3 (May-October, 1975): 51, and Shivji, Class Struggles, 79-99.

177 Shivji, Class Struggles, 107; Michael Schatzberg, Political Legitimacy in Middle Africa: Father Family, Food. (Bloomington, Indiana: Indiana University Press, 2001), 42.

178 Godfrey Mwakikagile, Nyerere and Africa: End of an Era. (Dar es Salaam: New 
Africa Press, 2010), 505.

179 Raikes, "Ujamaa and Rural Socialism," 48.

180 Hyden, Beyond, 123.

181 Ibid., 123-124.

182 Ibid., 124.

183 Ibid., 124-125.

184 Leander Schneider, "Freedom and Unfreedom in Rural Development: Julius Nyerere, Ujamaa Vijijini, and Villagization," Canadian Journal of African Studies / Revue Canadienne des Études Africaines 38, No. 2 (2004): 345; Leander Schneider, "Developmentalism and its Failings: Why Rural Development Went Wrong in 1960s and 1970s Tanzania," (PhD Dissertation, University of Michigan-Ann Arbor, 2003), 4-5; Hyden, Beyond, 113-123; Kelly Askew, Performing the Nation: Swabili Music and Cultural Politics in Tanzania. (Chicago: University of Chicago Press, 2002), 236; Nyerere, Socialism, 131. Nyerere asserted that socialist communities "cannot be established by compulsion." He states that communal living "depends on a willingness to cooperate" and that villages can only be "established with willing members." This statement is in direct conflict with his "operations" in Dodoma and Rufiji.

185 Schneider, "Freedom," 345; Schneider, "Developmentalism," 5; McHenry, "The Ujamaa in Tanzania," 44.

186 Schneider, "Developmentalism," 5; Nyerere, Man and Development, 38. Such is true when one examines Nyerere's 1973 statement that people "cannot be forced into ujamaa villages, nor told how to run them, but that does not mean that government and TANU have just to sit back and hope that people will be inspired to create them on their own... It is our job to explain what an Ujamaa village is, and to keep explaining it until the people understand."

187 Jean Francois Bayart, The State in Africa: The Politics of the Belly. (Cambridge: Polity Press, 2006), lxxxv.

188 Schatzberg states that the "fatherchief" has two major obligations: first, to feed his people, which Schatzberg refers to as the "family"; second, to punish his "children" when they misbehave.

189 Schatzberg, Political Legitimacy in Middle Africa, 1-4, 34-35; Bayart, The State in Africa, lxxxv-lxxxvi.

190 Schatzberg, Political Legitimacy in Middle Africa, 154. According to Schatzberg, the poem refers to Nyerere as "a hardworking mother."

191 Schatzberg, Political Legitimacy in Middle Africa, 213.

192 Hyden, Beyond, 123-124.

193 Ibid., 124.

194 Babu, African Socialism, 4, 146-147, 163-165.

195 Timothy Cheek, "Mao, Revolution, and Memory," in Cheek, ed., 13. 
196 Maurice Meisner, Marxism, Maoism and Utopianism: Eight Essays, (Madison: University of Wisconsin Press, 1982), 60; Dirlik et al., eds., 118-120.

197 Meisner, Marxism, 61; Dirlik et al., eds., 118-120.

198 Hyden, Beyond, 100; Xie Chuntao, Dayuejin Kuanglan [The Raging Waves of the Great Leap Forward]. (Zhengzhou, China: Henan Renmin Chubanshe, 1990), 72, as cited in Alfred L. Chan, Mao's Crusade: Politics and Policy Implementation in China's Great Leap Forward. (Oxford: Oxford University Press, 2001), 71;

McHenry, "The Ujamaa in Tanzania," 349.

It is uncertain if Nyerere ever learned that the Great Leap Forward fell short of its goals, or that the People's Communes failed to produce the results Mao intended.

199 Selden, The Yenan Way, 104, 244.

200 Schneider, "Freedom and Unfreedom," 352.

201 Ibid., 353; Nyerere, Freedom and Development, 68. Schneider quotes Nyerere as saying that "unless the purpose and socialist ideology of an ujamaa village is understood by the members from the beginning - at least to some extent - it will not survive the early difficulties.... And the greater self-discipline which is necessary when working in a community will only be forthcoming if the people understand what they are doing and why."

202 Schneider, "Freedom and Unfreedom," 355. According to Scheider, Nyerere's commitments to such ideals were mere qualifications from the beginning. He states that "while in the details of rural life and production, Nyerere was often willing to concede a considerable sphere of autonomy to the peasantry, the same cannot be said when it came to broader questions of greater strategic magnitude."

203 Mwakikagile, Nyerere and Africa, 505.

204 Ibhawoh and Dibua, "Deconstructing Ujamaa," 67; Mwakikagile, Nyerere and Africa, 505.

205 Schneider, "Freedom," 345. By January 1972 there were over 3,000 Ujamaa villages covering a population of 1.3 million-the tenth of the country's population.

206 Schneider, "Developmentalism," 4; McHenry, "The Ujamaa in Tanzania," $348,368-369$. By the early 1970s, several "operations" had been conducted to encourage people to enter the villages. By 1973, more than two million peasants had joined the fully collective farms.

207 Askew, Performing the Nation, 237.

208 Ibid., 236.

209 Ibid., 236-237.

210 Saul, "African Peasants," 67.

211 Nyerere, Freedom and Socialism, 29.

212 Ibid.

213 Babu, African Socialism, 146-147.

214 Mao Zedong, "We Must Learn to do Economic Work," Selected Works, Vol III, 241. Emphasis added. 
215 Mao Zedong, "The Situation and Our Policy After the Victory in the War of Resistance Against Japan,” Selected Works, Vol. IV, 20. Emphasis added.

216 Mao Zedong, "Introductory Note to "The Party Secretary Takes the Lead and All the Party Members Help Run the Cooperatives," In Quotations from Chairman Mao Zedong, (Beijing: Foreign Language Press, 1965), 112-113. Mao stressed the importance of having an active policy and effort towards the elimination of Third World dependency since it would make the Chinese revolution unstoppable.

217 Babu, African Socialism, 163.

218 Bailey, "Tanzania and China," 41-42.

219 Nyerere, Freedom and Socialism, 384-388, 390-391; Nyerere, Ujamaa: Essays on Socialism, 118-119; Nyerere, Man and Development, 24-41; Bailey, "Tanzania and China," 41-42.

220 Raikes, "Ujamaa and Rural Socialism," 48.

221 Ibid., 47; Ibhawoh and Dibua, "Deconstructing Ujamaa," 68; Nyerere, Ujamaa: Essays on Socialism, 119. Nyerere asserted that marketing "must be properly organized so that, even while our nation is in the grip of international market forces which control world prices, still we get the maximum possible for our goods, and our producers - that is, our farmers - get a fair return for their contribution to the national wealth."

222 Raikes, "Ujamaa and Rural Socialism," 47; Ibhawoh and Dibua, "Deconstructing Ujamaa," 68.

223 Raikes, "Ujamaa and Rural Socialism," 47, 51; Shivji, Class Struggles, 103-110; Ibhawoh and Dibua, "Deconstructing Ujamaa," 68, 70-71; Hyden, Beyond,133134.

224 Stuart Schram, Political Leaders of the Twentieth Century: Mao Tse-tung. (New York: Penguin Books, 1977), 243.

225 Stuart Schram, Mao Tse-tung. (New York: Penguin Books, 1977), 201.

226 Mao Zedo, “On the People's Democratic Dictatorship," in Selected Works, Volume IV, 421.

227 Babu, African Socialism, 4.

228 John Saul, "Frelimo and the Mozambique revolution," in Essays on the Political Economy of Africa, Giovanni Arrighi and John Saul eds., (London: Monthly

Review Press, 1973), 262; John Saul, "African Peasants and Revolution," Review of African Political Economy, No. 1 (August-September 1974): 57.

229 Nyerere, Socialism, 342-344. Emphasis added.

230 Other prominent African leaders, such as Kwame Nkrumah and Eduardo Mondlane forged successfully a worker-peasant alliance in Ghana and Mozambique respectively.

231 Nyerere, Freedom and Socialism, 407.

232 McHenry, "The Ujamaa in Tanzania," 359 


\section{CANADIAN COMMITTEE ON LABOUR HISTORY}

\section{LABOUR/LE TRAVAIL Journal of Canadian Labour Studies}

Labour/Le Travail began publishing in 1976, and has carried many important articles in the field of working-class history, industrial sociology, labour economics, and labour relations. While most articles have a historical perspective on Canadian workers, the journal is interdisciplinary in scope.

The journal also features documents, conference reports, an annual bibliography of materials in Canadian labour studies, review essays, and reviews. While the main focus of the journal's articles is Canada, the review essays and reviews consider international work of interest to Canadian labour studies.

Many of Labour/Le Travail's articles are illustrated and each issue is book length, averaging $350+$ pages. For a complete listing of volumes and articles, and to order online, visit the journal's website at www.cclh.ca

$\begin{array}{lll} & \text { Canada } & \text { International } \\ \text { Individual/individus: } & 1 \text { Year } \$ 25.00 & 1 \text { Year } \$ 35.00 \\ & 2 \text { Years } \$ 45.00 & 2 \text { Years } \$ 60.00 \\ & 3 \text { Years } \$ 60.00 & 3 \text { Years } \$ 80.00 \\ \text { Institutional/institutionnel: } & 1 \text { Year } \$ 35.00 & 1 \text { Year } \$ 55.00 \\ & 2 \text { Years } \$ 60.00 & 2 \text { Years } \$ 95.00 \\ \text { Student/étudiant(e)s: } & 1 \text { Year } \$ 15.00 & 1 \text { Year } \$ 30.00 \\ & 4 \text { Years } \$ 50.00 & 4 \text { Years } \$ 95.00\end{array}$

* Includes unemployed and retired./Cette categorie inclut les chomeurs ainsi que les retraites. All prices in Canadian dollars, make cheques payable to Athabasca University.

\section{BOOKS: Recent Publications of the CCLH}

The Struggle against Wage Controls: The Saint John Story, 1975-1976

jeorge Vair

SBN 1-894000-07-2, paperback, $\$ 19.95$

Fighting for Dignity:

The Ginger Goodwin Story

zoger Stonebanks

SBN:1-894000-06-4 paperback $\$ 26.95$

A Very Red Life:

The Story of Bill Walsh

jy Goniak

SBN:1-894000-05-6 paperback $\$ 24.95$

A Square Deal for All and No Railroading: Historical Essays on Labour in Brandon

irrol Black and Tom Mitchell, eds.

SBN:1-894000-03-X paperback \$24.95
Labouring the Canadian Millennium: Writings on Work and Workers, History and Historiography

Bryan D. Palmer, ed.

ISBN:1-894000-04-8 paperback $\$ 20.00$

NEW RELEASE:

Confrontation, Struggle and

Transformation: Organized Labour in the St. Catharines area

Carmela Patrias and Larry Savage

ISBN: 978-1-894000-08-6, paperback, \$14.99

For all our titles, and to order online, visit our website at www.cclh.ca

Send orders with payment to:

Athabasca University

c/o AU Press - CCLH

Peace Hills Trust Tower

1200, 10011-109 Street

Edmonton, AB T5J 358 Canada

Telephone: (780) 497-3412

E-mail: cclh@athabascau.ca

Facsimile: (780) 421-3298 